University of Wollongong

Research Online

Faculty of Science - Papers (Archive)

Faculty of Science, Medicine and Health

$1-1-2009$

\title{
Eoarchaean crustal growth in West Greenland (Itsaq Gneiss Complex) and in northeastern China (Anshan area): review and synthesis
}

\author{
Allen P. Nutman \\ University of Wollongong, anutman@uow.edu.au \\ Vickie C. Bennett \\ Australian National University \\ Clark R L Friend \\ Frances Jenner \\ Yusheng Wan
}

See next page for additional authors

Follow this and additional works at: https://ro.uow.edu.au/scipapers

Part of the Life Sciences Commons, Physical Sciences and Mathematics Commons, and the Social and Behavioral Sciences Commons

\section{Recommended Citation}

Nutman, Allen P.; Bennett, Vickie C.; Friend, Clark R L; Jenner, Frances; Wan, Yusheng; and Liu, Dunyi: Eoarchaean crustal growth in West Greenland (Itsaq Gneiss Complex) and in northeastern China (Anshan area): review and synthesis 2009, 127-154.

https://ro.uow.edu.au/scipapers/884

Research Online is the open access institutional repository for the University of Wollongong. For further information contact the UOW Library: research-pubs@uow.edu.au 


\title{
Eoarchaean crustal growth in West Greenland (Itsaq Gneiss Complex) and in northeastern China (Anshan area): review and synthesis
}

\begin{abstract}
Eoarchaean crust in West Greenland (the Itsaq Gneiss Complex, $3870-3600 \mathrm{Ma}$ ) is $>80 \%$ by volume orthogneisses derived from plutonic tonalite-trondhjemite-granodiorite (TTG) suites,3850, c. 3810 and c. 3710 Mahave some compositional similarities to modern island arc basalts (IAB), suggesting their origin by hydrous fluxing of a suprasubduction-zone upper mantle wedge. Most of the Eoarchaean tonalites match in composition high-silica, low-magnesian adakites, whose petrogenesis is dominated by partial melting of garnetiferous mafic rocks at high pressure. However, associated with the tonalites are volumetrically minor more magnesian quartz diorites, whose genesis probably involved melting of depleted mantle to which some slab-derived component had been added. This assemblage is evocative of suites of magmas produced at Phanerozoic convergent plate boundaries in the case where subducted crust is young and hot. Thus, Eoarchaean 'subduction' first gave rise to short-lived episodes of mantle wedge melting by hydrous fluxing, yielding IAB-like basalts \pm boninites. In the hotter Eoarchaean Earth, flux-dominated destructive plate boundary magma generation quickly switched to slab melting of ('subducted') oceanic crust. This latter process produced the voluminous tonalites that were intruded into the slightly older sequences consisting of tectonically imbricated assemblages of IAB-like pillow lavas + sedimentary rocks, gabbros and upper mantle peridotite slivers. Zircon datingshows that Eoarchaean TTG production in the Itsaq Gneiss Complex was episodic (3870, 3850-3840, 3820-3810, 3795, 3760-3740, 3710-3695 and $3660 \mathrm{Ma}$ ). In each case, emplacement of small volumes of magma was probably followed by 10-40 Maquiescence, which allowed the associated thermal pulse to dissipate. This explains why Greenland Eoarchaean crustal growth did not have granulite-facies metamorphismdirectly associated with it. Instead, 3660-3600 Ma granulite-facies metamorphism(s) in the Itsaq Gneiss Complex were consequential to collisional orogeny and underplating, upon termination of crustal growth. Similar Eoarchaean crustal history is recorded in the Anshan area of China, where a few well-preserved rocks as old as $3800 \mathrm{Ma}$ have been found including high-MgO quartz diorites. For $3800 \mathrm{Ma}$ rocks, this is a rare, if not unique, situation outside of the Itsaq Gneiss Complex. The presence of volumetrically minor 3800 Mamantle-derived high-MgO quartz diorites in both the Itsaq Gneiss Complex and the Anshan area indicates either that Eoarchaean 'subduction' zones were overlain by a narrow mantlewedge or that the shallow subduction trapped slivers of upper mantle between the conserved and consumed plates. (๑) The Geological Society of London 2009.
\end{abstract}

\section{Keywords}

greenland, west, growth, synthesis, review, area, anshan, china, crustal, northeastern, eoarchaean, complex, gneiss, itsaq, GeoQUEST

\section{Disciplines}

Life Sciences | Physical Sciences and Mathematics | Social and Behavioral Sciences

\section{Publication Details}

Nutman, A. P., Bennett, V. C., Friend, C. R L., Jenner, F., Wan, Y. \& Liu, D. (2009). Eoarchaean crustal growth in West Greenland (Itsaq Gneiss Complex) and in northeastern China (Anshan area): review and synthesis. Earth Accretionary Systems in Space and Time, 318 127-154.

Authors

Allen P. Nutman, Vickie C. Bennett, Clark R L Friend, Frances Jenner, Yusheng Wan, and Dunyi Liu 


\title{
Episodic Eoarchaean Crustal Accretion (3.87 to 3.66 Ga) in West Greenland (Itsaq Gneiss Complex) and in northeastern China
}

\author{
ALLEN P. NUTMAN ${ }^{1,2}$, VICKIE C. BENNET ${ }^{2}$, CLARK R.L. FRIEND ${ }^{3}$, FRANCES \\ JENNER $^{2}$, WAN YUSHENG ${ }^{1} \&$ LIU DUNYI $^{1}$ \\ ${ }^{1}$ Institute of Geology, Chinese Academy of Geological Sciences, 26 Baiwanzhuang Road, \\ Beijing, 100037, China \\ ${ }^{2}$ Research School of Earth Sciences, Australian National University, Canberra, ACT 0200, \\ Australia \\ ${ }^{3} 45$, Stanway Road, Headington, Oxford, OX3 8HU, UK
}

Corresponding author: Allen Nutman (e-mail: nutman@bjshrimp.cn) 
Abstract: Eoarchaean crust in West Greenland (Itsaq Gneiss Complex, 3.87-3.60 Ga) is $>80 \%$ by volume orthogneisses derived from plutonic tonalite-trondhjemite suites, $<10 \%$ amphibolites derived from basalts and gabbros, $<10 \%$ crustally-derived granite, $<1 \%$ metasedimentary rocks and $<<1 \%$ tectonic slices of upper-mantle peridotite. $>3.85, c$. 3810 and c. 3710 Ma amphibolites have some compositional similarities with modern island arc basalts (IAB), suggesting their origin by hydrous-fluxing of a supra-subduction zone upper mantle wedge. Most of the Eoarchaean tonalites match in composition high silica, low magnesian adakites, whose petrogenesis is dominated by partial melting of garnetiferous mafic rocks at high pressure. However, associated with the tonalites are volumetrically-minor more magnesian quartz-diorites - whose genesis probably involved melting of depleted mantle to which some slab-derived melt component had been added.

Like nowadays, Eoarchaean destructive plate boundaries would have initiated preferentially in the coldest (oldest), segments of oceanic crust, with the greatest density contrast between the consumed and conserved plates. Once initiated, Eoarchaean "subduction” gave rise to a short-lived episode of mantle wedge melting by hydrous-fluxing, to yield IAB-like basalts \pm boninites. In the hotter Eoarchaean Earth, destructive plate boundary magmatism soon switched over to predominantly melting in destroyed ("subducted”) crust. This produced the voluminous tonalites that were intruded into the marginally older sequences consisting of tectonically imbricated assemblages of IAB-like pillow lavas + sedimentary rocks, gabbros and upper mantle peridotite slivers. The presence of volumetrically minor high-MgO quartz-diorites suggests that mature Eoarchaean "subduction” zones were either overlain by a narrow mantle wedge, or that shallow subduction trapped slivers of upper mantle between the conserved and consumed plates.

Zircon dating shows that Eoarchaean TTG production in the Itsaq Gneiss Complex was episodic (3.87, 3.85-3.84, 3.82-3.81, 3.79, 3.76-3.74, 3.70-3.69 and 3.66 Ga). In each case, small volumes of magma were probably emplaced by "over-accretion", followed by 10 to 40 million years quiescence, which allowed the associated thermal pulse to dissipate. This explains why Greenland Eoarchaean crustal accretion did not have granulite facies metamorphism directly associated with it. Instead, 3.66-3.60 Ma granulite facies metamorphism(s) in the Itsaq Gneiss Complex were related to collisional orogeny and underplating, upon termination of crustal accretion. Similar Eoarchaean crustal accretion history is recorded in the Anshan area of China. 
Keywords: Eoarchaean, tonalites, Island Arc Basalts, Crustal accretion, Convergent plate boundaries.

The first Rb-Sr isotopic studies (Moorbath et al. 1972; Moorbath 1975) of the then oldestknown Eoarchaean orthogneisses from West Greenland recognised that their primitive (i.e. low initial ${ }^{87} \mathrm{Sr} /{ }^{86} \mathrm{Sr}$ ) signatures meant they represented "juvenile" (i.e., derived from the mantle shortly before their genesis) material, accreted (added) into the crust, and that they were not "reworked" from appreciably older Hadean (>4000 Ma) rocks. This interpretation was coupled with the recognition that these ancient rocks were derived largely from tonalitic plutonic protoliths (McGregor 1973) with a likely origin by melting of mafic rocks (McGregor 1979; O’Nions \& Pankhurst 1974). Rocks of such compositions are overwhelmingly produced at convergent plate boundaries (see Martin 1999 for summary). Thus ever since the 1970s, it has been proposed that crustal accretion processes, with at least some resemblance to modern ones, operated at least as far back in time as the Eoarchaean (3.5-4.0 Ga). Although there are many differences in the evidence cited and methodology used, subsequent studies of Greenland Eoarchaean crustal evolution concur with Moorbath (1975) that Eoarchaean rocks are dominated by crustal accretion products, and it has been proposed that they formed at convergent plate boundaries (e.g. Nutman \& Collerson 1991; Bennett et al. 1993; Nutman et al. 1993, 1996, 2000, 2002a,b; Komiya et al. 1999; Polat et al. 2002, Polat \& Hofmann 2003; Hamner \& Greene 2002; Steenfelt et al. 2005; Furnes et al. 2007).

This paper examines the nature of very ancient crustal accretion by focussing on the rich Eoarchaean geological record of West Greenland, preserved within the Itsaq Gneiss Complex (Fig. 1). This is then compared with the more scanty Eoarchaean geological record of China (Liu et al. 1992; Song et al. 1996; Wan et al. 2005) and contrasted with Phanerozoic crustal accretionary systems.

\section{Eoarchaean geological record of West Greenland (Itsaq Gneiss Complex) and understanding ancient crustal accretion}

\section{Study of modern versus ancient crustal accretion}

Subduction zones and other related components of modern convergent plate boundaries where crustal accretion is currently taking place can be studied in great detail, using a barrage of different methods, ranging from deep seismic imaging (e.g. tomography), charting cm-scale relative crustal motions using GPS, structural geology and numerous 
geochemical and isotopic analytical techniques (as described in this volume). However, the Eoarchaean crustal rocks that are interpreted as the products of crustal accretion at convergent plate boundaries, are only preserved as small fragments in younger MesoNeoarchaean orogens, where they suffered repeated post-accretion deformation and metamorphism (see Nutman 2006 for summary). Thus compared with modern settings, a much narrower range of information can be obtained from these Eoarchaean rocks. Information from these Eoarchaean rocks is heavily biased towards geochemical and isotopic data, with use of structural information limited to very rare areas where postaccretionary strain was low. Thus in studying the Eoarchaean geological record, there is neither hope of identifying fossil subduction zones (as revealed by seismic studies of the Neoarchaean Superior Province greenstone-granite terrane of Canada - Calvert et al. 1995) nor original plate boundaries and palaeo-geographies.

\section{Geological setting of the Itsaq Gneiss Complex}

In West Greenland, Eoarchaean rocks occur in the Nuuk region (Fig. 1), where they crop out for only about $3000 \mathrm{~km}^{2}$, and are known collectively as the Itsaq Gneiss Complex (Nutman et al. 1996, 2004). This complex constitutes at least a quarter of the preserved global Eoarchaean geological record, and hence is smaller than many single islands in a modern island arc! This comparison gives an idea the scale of the surviving Eoarchaean geological record. Additionally, the Itsaq Gneiss Complex Eoarchaean crustal accretion products were affected by latest Eoarchaean (<3660 Ma) high-grade metamorphism and deformation events (Griffin et al. 1980, Nutman et al. 1996; Friend \& Nutman 2005a). We interpret these latest Eoarchaean events to be unrelated to the crustal accretion, but to be linked instead to a collisional orogeny that terminated the accretion (Friend \& Nutman 2005a). Thus the products of likely Eoarchaean crustal accretion are preserved mostly as strongly deformed amphibolite-granulite facies gneisses, from which it is hard to extract any detailed information concerning their origins (Fig. 2a). However, locally there are low strain domains where some more detailed information on Eoarchaean crustal accretion can be gathered (Fig. 2b). Most of these are in and around the Isua supracrustal belt (Fig. 1) an area that since the early 1970s (Moorbath et al. 1973; McGregor \& Bridgwater 1974; Allaart 1976) has been an enduring focus of research into Eoarchaean geology.

The Itsaq Gneiss Complex occurs as mylonite-bounded tectonic slivers within a collage of younger terranes (each terrane has its own rock ages and internal 
evolution). The Itsaq Gneiss Complex in the Nuuk region is represented by the Isukasia terrane to the north (with the Isua supracrustal belt) and the Færingehavn terrane to the south (Fig. 1). These terranes were assembled with younger rocks during several Neoarchaean tectonothermal events (Friend et al. 1988; Friend \& Nutman 2005b). Thus the Eoarchaean rocks are allochthons found within a Neoarchaean orogen (McGregor et al. 1991; Friend \& Nutman 2005b).

The Itsaq Gneiss Complex contains $>95 \%$ quartzo-feldspathic rocks of intrusive origin, now mostly strongly deformed into orthogneisses. The rare areas of relatively little deformation show that these usually formed from older tonalite and younger granite components (Fig. 2b). All researchers (e.g. Steenfelt et al. 2005) agree that the tonalites are compositionally like Archaean TTG (tonalite-trondhjemitegranodiorite). True (potassic) granites also occur (Nutman et al. 1984a, 1996; Nutman \& Bridgwater 1986; Crowley et al. 2002). These were formed largely by melting of crust dominated by tonalite (Baadsgaard et al. 1986). Volcanic and sedimentary (supracrustal) rocks form $<5 \%$ of the Complex. These are scattered through the banded gneisses as enclaves and tectonic slivers, and range in size from the 35-km long Isua supracrustal belt (e.g. Moorbath et al. 1973; Allaart 1976; Nutman et al. 1984b, 1997, 2002b; Komiya et al. 1999) down to much smaller pods (McGregor \& Mason 1977; Nutman et al. 2002a). Volcanic and sedimentary rocks are dominated by associations of banded and commonly skarn-bearing amphibolites, with lesser amounts of quartz-magnetite banded iron formation (BIF), marbles, siliceous rocks and calc silicate rocks. In the amphibolites, rare occurrences of relict pillow lava structure have been found (Fig. 3a; Komiya et al. 1999; Solvang 1999; Furnes et al. 2007). Several investigations have interpreted the BIF, siliceous and calc-silicate lithologies together as a variegated suite of chemical sediments (Fig. 3b; e.g., Nutman et al. 1984; Dymek \& Klein 1988; Dauphas et al. 2004; Bohlar et al. 2005). Less common are felsic schists and pelites, for which all those agreed to have a volcano-sedimentary rather than metasomatic origin, are in the Isua supracrustal belt (e.g. Nutman et al. 1984b, 1997 2002b; Kamber et al. 2005). Metagabbros, locally grading into anorthosites (Fig. 3c) also occur, and are usually spatially associated with layered metaperidotites (Chadwick \& Crewe 1986; Nutman et al. 1996; Friend et al. 2002). These are fragments of layered (basic) intrusions. Other ultramafic rocks are highly magnesian, with very low alumina and lime. Most of 
these are metasomatised amphibolite \pm phlogopite-bearing schists. However, very rarely, they are much better preserved, and occur as fine-grained olivine + orthopyroxene \pm aluminous spinel \pm amphibole dunites and harzburgites (Nutman et al. 1996; Friend et al. 2002).

The Isukasia terrane of the northern part of the Nuuk region and contains the Isua supracrustal belt (Fig. 1). Around the Isua supracrustal belt there are most of the world's occurrences of Eoarchaean rocks preserved in a low strain state, plus the area as a whole has only suffered (multiple) amphibolite facies metamorphism, rather than granulite facies metamorphism as in other parts of the complex (Griffin et al. 1980; Nutman et al. 1996). In the northern parts of the Isukasia terrane (north of line “N” in Fig. 1), c. 3500 Ma Ameralik dykes are only weakly to non-deformed. This shows that the amount of Neoarchaean deformation is generally low (Bridgwater \& McGregor 1974; Allaart, 1976). In places north of line “N”, Eoarchaean rocks are almost undeformed but elsewhere, such as at the northern edge of the Isua supracrustal belt (Fig. 4), there are Eoarchaean mylonites (Nutman 1984; Nutman et al. 1997, 2002a; Crowley et al. 2002). These low strain domains show that in the Isukasia terrane, in situ melting was very limited (Nutman et al. 1996), greatly aiding in the interpretation of these rocks. The southern edge of the Isukasia terrane is more deformed, and consists of banded gneisses resembling in appearance those of the Færingehavn terrane (Bridgwater \& McGregor 1974; Nutman et al. 1996).

The Færingehavn terrane is where terrestrial >3600 Ma rocks were first identified (Black et al. 1971; McGregor 1973). The type locality of these was Amîtsoq (using the old Greenlandic orthography) on the north shore of Ameralik (fjord), and hence the Eoarchaean banded orthogneisses became known as the Amîtsoq gneisses (McGregor 1973). McGregor and his collaborators abandoned this term in 1996, when instead they became regarded as the dominant part of the Itsaq Gneiss Complex (Nutman et al. 1996). The Færingehavn terrane occurs in the central and southern part of the Nuuk region (Fig. 1). Overall its rocks are much more modified by strong deformation and high-grade metamorphism than the northern parts of the Isukasia terrane. This makes it harder to obtain unequivocal interpretations of its rocks. In rare domains of lower strain in the Færingehavn terrane tonalitic protoliths can still be locally well preserved (Nutman et al. 2000, in press), and it is seen that 
the granitic components are derived from in situ melting of the tonalites and from intrusions. These latter events have been equated with petrographic evidence for Eoarchaean granulite facies metamorphism in the Færingehavn terrane (McGregor \& Mason 1977; Griffin et al. 1980). Units of c. 3640 Ma (Baadsgaard 1973) Fe-rich augen granites, monzonites and ferro-gabbros are a distinct component of the southern part of the Færingehavn terrane (McGregor 1973). These rocks are the product of hybridisation of magmas derived from the mantle and the deep crust, and resemble A-type / within-plate-granites with high $\mathrm{Nb}, \mathrm{Zr}, \mathrm{TiO}_{2}$ and $\mathrm{P}_{2} \mathrm{O}_{5}$ (Nutman et al. 1984a, 1996). The Færingehavn terrane orthogneisses contain lenses of amphibolites, ultramafic and siliceous rocks, named the Akilia association by McGregor \& Mason (1977). Although it is agreed that these largely represent enclaves of mafic volcanic rocks, gabbros and chemical sediments, there is lack of agreement concerning their age, because in most places the original relationship with the surrounding orthogneisses has in most places been obliterated by migmatisation and high strain (Nutman et al. 2000, 2002a). Nutman et al. (1996, 2000) and Friend \& Nutman (2005a) presented evidence that the Akilia association represents the remains of several supracrustal sequences, ranging from $\geq 3850$ Ma to 3650-3600 Ma. However, Whitehouse et al. (1999) and Whitehouse \& Kamber (2005) consider that there is not yet strong enough evidence for any of the Akilia association being $\geq 3850$ Ma.

\section{Isua supracrustal belt and surrounding gneisses}

Isua supracrustal belt

Despite that the Isua supracrustal belt escaped much deformation in the Neoarchaean, most of it still strongly deformed due to Eoarchaean deformation (Nutman et al. 1984b, 2002a, Myers, 2001). Thus, in most places, primary volcanic and sedimentary structures were obliterated, and outcrop-scale compositional layering is of mostly transposed tectonic origin. It is only in rare augen of total low strain that volcanic and sedimentary structures are preserved. Unequivocal pillow structures in Isua supracrustal belt amphibolites (Komiya et al. 1999; Solvang, 1999; Furnes et al. 2007) are important, because they demonstrate that most Isua amphibolites were derived from subaqueous volcanic rocks (Fig. 4a). This contrasts with previous ideas held in the 1970s and 1980s that amphibolites derived from 
gabbros were an equally important component in the belt as metavolcanic ones (e.g., Nutman et al. 1984b).

Rocks of chemical sedimentary origin such as banded iron formation (Moorbath et al. 1973; Dymek \& Klien 1988) have quartz and either calc-silicate or magnetite layering. This is mostly a transposed layering, and only locally does it represent original (albeit still deformed) sedimentary structure (Fig. 4b). There are two prominent felsic schist units. The first one is restricted to the northeastern end of the belt and has yielded several zircon dates of c. $3710 \mathrm{Ma}$ and there is agreement that it is a felsic volcano-sedimentary unit (Nutman et al. 1997, 2002b; Kamber et al. 2005). The second unit crops out throughout the length of the belt, and has in several places yielded zircon dates of c. 3800 Ma (e.g. Baadsgaard et al. 1984; Compston et al. 1986; Nutman et al. 2002b). For this unit there is lack of agreement whether it is a (metasomatised) felsic volcanic rock (Allaart 1976; Nutman et al. 1984b), an altered tonalitic intrusion (Rosing et al. 1996) or metasomatised basalt (Myers 2001).

Based on early 1980s mapping, Nutman et al. (1984b) regarded the Isua supracrustal belt as fragments of one or possibly two volcano-sedimentary sequences (“A” and “B”), disrupted by early tectonic breaks. At that time there was only zircon geochronology on one outcrop of felsic rocks in the belt - with ages of $c$. 3800 Ma being obtained (MichardVitrac et al. 1977; Baadsgaard et al. 1984). Other age constraints then came from a whole rock $\mathrm{Pb}-\mathrm{Pb}$ errorchron of 3710 $\pm 70 \mathrm{Ma}$ (Moorbath et al. 1973), an Sm-Nd errorchron of $3770 \pm 42 \mathrm{Ma}(2 \sigma)$ for a mixed suite of felsic and mafic rocks (Hamilton et al. 1978), and $\mathrm{Rb}-\mathrm{Sr}$ whole rock Eoarchaean errorchrons ( $\pm>50$ million years) for orthogneiss components invading and surrounding the belt (e.g. Moorbath et al. 1972, 1977). Within this early geochronological framework, it was considered that the Isua supracrustal rocks were all related - a concept then widely accepted for all other ancient volcano-sedimentary sequences, such as the Barberton Greenstone Belt. With the start of a broader SHRIMP U$\mathrm{Pb}$ zircon-dating programme with rock ages with uncertainties of $\leq \pm 5 \mathrm{Ma}$, it was realised that the belt contains supracrustal rocks varying in age by 100 million years, and hence the earlier "stratigraphy” was abandoned (Nutman et al. 1997). Thus the belt's southern part is dominated by c. 3800 Ma rocks, whereas along its northern and central reaches $c .3700 \mathrm{Ma}$ rocks are present (e.g. Fig. 4; Nutman et al. 1996, 1997, 2002b; Crowley 2003; Kamber et al. 2005). Nutman et al. (1997) proposed that these unrelated sequences were separated by 
Eoarchaean mylonites. Subsequent studies concur with this interpretation, with Komiya et al. (1999), Appel et al. (1998), Myers (2001), Nutman et al. (2002b, in press a) all indicating mylonites in their mapping, to divide the belt into Eoarchaean panels of unrelated rocks.

\section{Orthogneisses adjacent to the Isua supracrustal belt}

The Isua supracrustal belt is bounded to the north by orthogneisses, whose main components are 3700-3690 Ma tonalites, and several suites of 3660-3630 Ma granites and pegmatites (Nutman \& Bridgwater 1986; Nutman et al. 1996, 2000, 2002b; Crowley et al. 2002). The contact between these and the Isua supracrustal belt is an Eoarchaean shear zone (Nutman 1984; Nutman et al. 1997, 2002b), which probably formed at c. $3650 \mathrm{Ma}$ (Crowley et al. 2002).

Although superficially similar in the field, the tonalites and their gneissified equivalents on the south side of the Isua supracrustal belt are older than those to the north, with ages of 3810-3795 Ma (Nutman et al. 1996, 1999, 2000; Crowley 2003). Furthermore, metabasaltic amphibolites along the southern side of the belt are intruded by c. $3800 \mathrm{Ma}$ tonalites, giving their minimum age (Nutman et al. 1996, 1997; Crowley 2003). Hence, the southern margin of the belt is a strongly deformed intrusive contact, whereas the northern contact is an Eoarchaean mylonite (Fig. 4). In the southern tonalite area there are 36603630 Ma granitic sheets, but they are less voluminous than those cutting the tonalites to the north. The southern 3800 Ma tonalites contain more inclusions of mafic and ultramafic rocks than the northern 3700 Ma tonalites.

Both the northern and southern tonalites contain rare areas of very low total strain, where even igneous textures (weakly plagioclase phyric) and structures (brecciation of weakly foliated tonalite by homogeneous 3800 Ma tonalite - Fig. 2c) are preserved. Despite the low strain, even these rocks have been thoroughly recrystallised, and no igneous phases (apart from zircons and in the northern tonalites rarely centres of plagioclase) are preserved. Associated with the tonalites are lesser volumes of quartz diorites, with the same age as the tonalites (Nutman et al. 1999). 


\section{Tectonic features related to Eoarchaean accretion}

In the Isua supracrustal belt, rocks of different age and origin are tectonically juxtaposed together, with the tectonic contacts then folded. As shown in the eastern part of the Isua supracrustal belt (Fig. 4) these mylonites must be Eoarchaean, because an amphibolitised mafic dyke cutting a mylonite has yielded a zircon age of c. 3500 Ma (Nutman et al. in press b). Furthermore, the mylonite marking the northern edge of the belt probably formed at c. 3650 Ma (Crowley et al. 2002). Thus the Isua supracrustal belt is clearly the site of Eoarchaean tectonic intercalation of different packages of rocks. However, in the Isua supracrustal belt the absolute age constraints on Eoarchaean mylonites is sparse, and a relationship between these Isua Eoarchaean mylonites and the juvenile tonalite suites produced by accretion is not found. Thus it is as yet unknown to what extent tectonic intercalation in the Isua supracrustal belt occurred during crustal accretion, or shortly afterwards during collisional orogeny.

The 3800 Ma tonalitic gneisses south of the Isua supracrustal belt contain a mixed inclusion suite of skarned amphibolite with some BIF from the upper crust, layered gabbros with layered peridotites from deeper within the crust and slivers and pods of dunite and harzburgite derived from the upper mantle (Fig. 5a; Nutman et al. 1996, 2002b; Friend et al. 2002). This inclusion assemblage is dissected by Eoarchaean mylonites. Granitic lithons in mylonite and deformed granite sheets cutting some mylonites have yielded zircon dates of 3630-3600 Ma (Nutman et al. 2002b; Friend et al. 2002). Hence, such Eoarchaean mylonites are >150 million years younger than the tonalites that mark crustal accretion in this area. Such mylonites must have formed during younger orogenic events superimposed on the tonalitic products of crustal accretion. However, in some cases, earlier mylonites have been detected between mantle dunite/harzburgite slivers and crustal rocks, such as layered gabbros and cumulate layered ultramafic rocks (Fig. 5b). These mylonites pre-date $c .3800$ Ma tonalite/trondhjemites that engulf the ultramafic and mafic rocks (Nutman et al. 1996; Friend et al. 2002). These indicate that mantle rocks and rocks from different crustal levels were being tectonically intercalated prior to being engulfed and "exploded” by tonalite intrusions. This is strong field evidence for a synkinematic regime for tonalite emplacement during (c. $3800 \mathrm{Ma}$ ) Eoarchaean crustal accretion. This would mean that during crustal accretion, many tonalite bodies could be already foliated and even gneissified, prior to deformation and high-grade metamorphism 
superimposed during later unrelated orogenic events. Rare examples of jumbled blocks of foliated tonalite set in a matrix of homogeneous tonalite (Fig. 2c), dated at c. 3800 Ma. (Nutman et al. 1999) is also evidence for this.

\section{Geochronological framework}

Age of supracrustal and mantle rocks

Archaean volcano-sedimentary sequences dominated by mafic volcanic rocks and chemical sediments are notoriously difficult to date accurately and precisely, because they do not crystallise igneous zircon when they form. Instead, some age constraints can be obtained by dating discordant tonalite sheets within them, as has been done for amphibolites in southern edge of the Isua supracrustal belt and amphibolites and ultramafic rocks to the south (Nutman et al. 1996, 1997, 1999; Friend et al. 2002; Crowley 2003). In other instances, rare small oscillatory-zoned euhedral zircons have been extracted from chemical sediments in the belt and have given ages of $c$. $3700 \mathrm{Ma}$ (Nutman et al. 2002b, in press b). These are interpreted as a small volcanogenic component that fell into chemical sedimentary sequences, thereby given a proxy age of $c$. 3700 Ma. In more fortunate cases, graded felsic volcanosedimentary rocks in the northeast of the belt contain abundant igneous zircon, and have yielded direct dates of c. 3700 Ma (Fig. 6; Nutman et al. 1996; 1997, 2002b; Kamber et al. 2005).

Age of banded gneisses, tonalites and quartz-diorites

Whitehouse et al. (1999) identified multiple generations of oscillatory-zoned igneous zircons in samples of banded gneisses from the Færingehavn terrane. They interpreted the youngest oscillatory-zoned zircons as giving the igneous age of single protoliths, with all older zircons being xenocrysts. Nutman et al. $(2000,2004)$ pointed out that as such rocks are actually complex banded gneisses, an equally permissible, if not more likely, interpretation is that several ages of igneous material are present in such rocks. Such diversity of opinion shows that working on single-component rocks from low strain zones rather than banded gneisses is important to avoid ambiguity in the interpretation of (expensive) geochronological data. By focussing geochronology on low strain domains, Nutman et al. (1993, 1996, 2000, 2002a, in press a) proposed that tonalites within the Itsaq Gneiss Complex are c. 3850, 3800, 3760-3730, 3700 and 3660 Ma old (Fig. 6). Detailed 
arguments for this can be found in Nutman et al. (2000, 2004, in press a) and Mojzsis \& Harrison (2002).

\section{Eoarchaean island arc basalts, “boninites”, upper mantle peridotites, tonalites and quartz-diorites}

Gill et al. (1981) noted that some Isua supracrustal belt banded amphibolites had compositional affinities with some modern arc basalts. More recent studies have focussed on rare strain zones in Isua amphibolites, particularly where pillow centres can be sampled separately from pillow rims and interstitial material (Polat et al. 2002; Polat \& Hofmann, 2003; Jenner et al. 2006). Careful sampling allows chemical signatures that are original to the volcanic protoliths to be discriminated from those caused by metasomatism, on the seafloor and later during high-grade metamorphism and deformation (Polat \& Hofmann 2003). The trace element chemistry of recent suites of Itsaq Gneiss Complex amphibolites indicates that they were derived from rocks whose closest modern analogues are island arc basalts (IAB), rather than being plume related or mid ocean ridge basalt (Table 1; Polat \& Hofmann 2003). Diagnostic signatures are depletions in $\mathrm{Ti}$ and $\mathrm{Nb}$ and (variable) enrichments in $\mathrm{Pb}, \mathrm{Sr}, \mathrm{Ba}, \mathrm{Rb}$ (Fig. 7). Within the Isua supracrustal belt, rocks in the belt's southern edge of IAB affinity (Fig. 7a; Jenner et al. 2006) certainly have an age of c. 3800 Ma, whereas other suites with IAB affinity in the northern side of the belt (Fig. 7b; Polat \& Hoffman, 2003) are interlayered with BIF/metachert with c. 3710 Ma old volcanosedimentary zircons (Nutman et al. 2002b) and thus are probably c. 3710 Ma old. Amphibolites of IAB affinity also occur on the islands of Akilia and Innersuartuut, in the Færingehavn terrane (Fig. 1; Cates \& Mojzsis 2006; Jenner et al. 2006; Jenner 2007). Although in the Færingehavn terrane volcanic structures are not preserved, careful sampling to avoid superimposed metasomatism has revealed geochemical traits similar to those seen in better-preserved rocks in Isua (Fig. 7c). From zircon dating of tonalitic components of the gneiss complex that invade and surround these mafic rocks, Nutman et al. (1996, 1997, 2002b, 2004, in press a), Mojzsis \& Harrison (2002), Krogh et al. (2003) and Manning et al. (2006) interpret such amphibolites on Akilia and Innersuartuut as $>3850$ Ma old. As such, these rocks with remnants of IAB geochemical signatures are the world's oldest-preserved mafic crust. However, it should be noted that others (e.g. Whitehouse \& Kamber, 2005) dispute our evidence that these rocks are as old as 3850 Ma. 
Within the Isua supracrustal belt, the prominent unit of "boninitic" amphibolite (Fig. 4) is distinguished from neighbouring amphibolites of differing composition by its high-MgO and lower HFSE ( $\mathrm{TiO}_{2}<0.4$ wt\%; $\mathrm{Zr}<30$ ppm; $\mathrm{Nb}<0.13$ ppm; $\mathrm{Y}<14 \mathrm{pp}-$ Polat et al. 2002, Polat \& Hofmann, 2003). They also show pronounced enrichment in $\mathrm{Pb}$ and $\mathrm{Sr}$. Representative analyses of these are given in Table 1 and their trace element chemistry is shown in Figure 7d. Polat and co-workers have likened the chemistry of the garbenscheifer unit to that of boninites found in modern arc-backarc settings. Although the exact analogy with modern boninites might be debated, the high-MgO of these rocks clearly requires more extensive melting of an already depleted mantle source than the IAB (Polat et al. 2002; Jenner et al. 2006). This would indicate elevated mantle temperatures and/or increased fluxing of mantle by (slab-derived) fluids, as corroborated by the enrichment in $\mathrm{Pb}$ and $\mathrm{Sr}$ (Polat et al. 2002). In a modern setting, this occurs in the most juvenile stages of island arc systems (see Shervais et al. 2001 for review). There is no direct precise date for the "boninitic" amphibolite unit(s). Attempts to date it by the Sm-Nd whole rock method gave ages between 3700-3800 Ma with uncertainties $> \pm 40$ million years (e.g. Hamilton et al. 1978; Rosing 1999). Felsic intermediate volcano-sedimentary rocks of likely arc derivation that are intimately interlayered or interdigitated with the "boninitic" unit contain c. 3710 Ma detrital zircons (Nutman et al. 1997, 2002b). Thus as a working hypothesis, we consider that c. $3700 \mathrm{Ma}$ is the likely age for the "boninitic" unit. Although amphibolites of "boninitic" chemistry have been most widely documented from the Isua supracrustal belt, there are some amphibolites (>3850 Ma?) in the Færingehavn terrane on Akilia island with similar, but less extreme compositional traits (Jenner 2007).

Gabbros and related layered ultramafic rocks and anorthosites that they grade into occur in small amounts (Table 1). These rocks are now thoroughly recrystallised, such that no igneous phases are preserved. However, compositional variation of well-preserved suites indicate control by plagioclase, pyroxene and olivine fractionation, not amphibole (Jenner 2007). Thus prior of metamorphism with amphibolitisation, these were anhydrous intrusions. As the gabbros are derived from layered complexes (Fig. 3c), their protoliths were mixtures of residual and trapped liquid + calcic plagioclase + pyroxene \pm olivine \pm chromian spinel. Despite being crystal-liquid mixtures, trace element variations such as negative $\mathrm{Ti}$ and $\mathrm{Nb}$ anomalies in trace-element spidergrams show that their parental liquids also had affinities with IAB, rather than komatiites or MORB (Jenner 2007). Thus these 
rocks have a close compositional affinity with the associated supracrustal amphibolites of the Itsaq Gneiss Complex.

Highly-magnesian (up to $48 \mathrm{wt} \%$ ) dunites and harzburgites with low alumina ( $<5.5 \mathrm{wt} \%$ but generally much lower) and low lime ( $<2 \mathrm{wt} \%)$ are locally preserved as small relict cores within larger amounts of amphibole-rich ultramafic schists (Table 1; Nutman et al. 1996; Friend et al. 2002). The dunites and harzburgites are generally massive and devoid of compositional layering, in contrast with the layered peridotites that grade into gabbros. Locally, finer-grained varieties are transected by course-grained olivine-rich channels, which predate crustal hydration and metasomatism that these ultramafic bodies have suffered. These ultramafic rocks most commonly occur as isolated pods completely surrounded by orthogneisses, or more rarely, in tectonic contact with crustal rocks, and then surrounded by tonalitic gneisses (Fig. 5b; Nutman et al. 1996; Friend et al. 2002). Olivine in these rare well-preserved rocks have fo89-90 compositions, and can contain inclusions of aluminous spinel (Friend et al. 2002). Spinels from one of these dunites (G93/42 on Fig. 5a) have given the most primitive measured terrestrial ${ }^{187} \mathrm{Os} /{ }^{188}$ Os isotopic ratio (Bennett et al. 2003). In terms of bulk compositions (e.g. Al/Si versus $\mathrm{Mg} / \mathrm{Si}$, Fig 8), the dunites and harzburgites follow the mantle fractionation trend, with many samples being strongly depleted. Hence, they bear no resemblance to either komatiites or cumulate peridotites from layered complexes (Fig. 8). Instead, they are interpreted as slivers of Eoarchaean upper mantle. South of the Isua supracrustal belt, these slivers had already been tectonically intercalated with crustal rocks when $c$. 3800 Ma tonalites were intruded (Nutman et al. 1996; Friend et al. 2002). Thus their emplacement into the crust was part of the accretion process.

Tonalites are siliceous (typically 65-70 wt\%) potassium-poor intrusive rocks that are the most voluminous of all Archaean rock types. Geochemical and experimental petrological research show that Archaean tonalites were generated by melting of hydrated mafic crust, after transformation into garnet amphibolite or eclogite (summary by Martin et al. 2005). Adakites are the modern compositional analogues of Archaean tonalites, and they form exclusively at convergent plate margins by predominantly partial melting of $<20$ million years old subducted slab (oceanic crust). Therefore, it is generally considered that Archaean tonalites formed in a broadly similar fashion at ancient convergent plate boundaries. Sr, Nd and $\mathrm{Hf}$ isotopic studies show that tonalites of the Itsaq Gneiss Complex 
are juvenile "continental” (silica-saturated) crustal material, whose source materials had been extracted from the mantle only shortly before (e.g. Moorbath et al. 1972; Moorbath 1975; Bennett et al. 1993; Vervoort et al. 1996). In terms of major element chemistry (Table 1), the Itsaq Gneiss Complex tonalites mostly fall in the high silica, low magnesian field for older TTG (Fig. 9a). In terms of their trace element variation, they show enrichment of the light REE over heavy REE elements, indicative of the role of residual garnet in their source region preferentially retaining the heavy REE (Fig. 9b; Arth \& Hanson 1975; Martin 1986, onwards). Trace element modelling (Nutman et al. 1999) of some $c$. 3800 Ma tonalites demonstrated that they could be produced by 30\% partial melting of an eclogite source, whose protolith in turn was formed by $30 \%$ melting of depleted upper mantle (Rb versus Sr/Y, Fig. 9c). However, average Archaean tonalite and many Itsaq Gneiss Complex compositions lie to the right of this model eclogite-melting curve (Fig. 9c). Such compositions can arise from permutations of plagioclase fractionation, melting of garnet amphibolite rather than eclogite sources and contributions from melting in the upper mantle.

Associated with the tonalites are much smaller volumes of quartz-diorite. These have been detected in the c. $3800 \mathrm{Ma}, 3700 \mathrm{Ma}$ and $3660 \mathrm{Ma}$ suites (Table 1). They have lower silica (55 to 60 wt\%) and higher MgO (3 to 4 wt\%; Fig. 9a), with \#Mg values approaching 50. As pointed out by Smithies \& Champion (2000), the highly magnesian character of such rocks means that they cannot have been derived solely by melting of basic rocks, but must have involved some melting of high \#Mg mantle ultramafic rocks fluxed by fluids as well. Thus it appears that although crustal accretion in the Itsaq Gneiss Complex largely involved emplacement of tonalites whose petrogenesis was dominated by the melting of (hydrated) basaltic rocks at high pressure (Nutman et al., 1999; Steenfelt et al., 2005), there was also some contribution to siliceous magmas from the melting of (metasomatised) mantle rocks.

\section{Thermal characteristics of the crustal accretion that formed the Itsaq Gneiss Complex}

The Itsaq Gneiss Complex consists $>80 \%$ by volume of orthogneisses derived from tonalite protoliths. Numerous experimental studies (e.g. Wyllie et al. 1997; Rapp 1997) indicate that parental tonalite magmas are hot $\left(>900^{\circ} \mathrm{C}\right)$, water-undersaturated and have 
positive $\mathrm{dP} / \mathrm{dT}$ for their solidi. This solidi characteristic permits magmas to rise from their source regions without freezing (Brown \& Fyffe 1970). Additionally, tonalite magmas have a likely specific gravity of 2.4-2.5 (Groves \& Baker 1983), which is considerably less than the 2.7-3.0 specific gravity for the assemblage of predominantly mafic rocks they were intruded into. Therefore, tonalite magmas should be emplaced into high levels in the crust - a mode of tonalite intrusion termed as overaccretion by Wells (1980).

Intuitively, if the emplacement of a given volume of $>900^{\circ} \mathrm{C}$ tonalite magma as several pulses is spread over a longer time, then it is less likely to cause regional high grade metamorphism. This is because the heat from one magma pulse can be dissipated by conduction before intrusion of the next pulse. On the other hand, intrusion of TTG magmas as several pulses in a short period will result in more elevated crustal temperatures, with an increased likelihood of $>800-850^{\circ} \mathrm{C}$ with dehydration-melting reactions and hence granulite facies metamorphism. Wells (1980) studied this quantitatively by onedimensional conductive relaxation models, for continental crust undergoing magmatic thickening in a predominantly recumbent tectonic regime (i.e. crustal accretion). Some overaccretion scenarios presented by Wells (1980) are reproduced here in Fig. 10. They clearly demonstrate that rapid accretion ( $<10$ million years) results in sustained elevated $800-850^{\circ} \mathrm{C}$ temperatures at depth in the crust, that are suitable for causing granulite facies metamorphism. On the other hand, slow episodic accretion (using Wells' 3 intrusive pulses in 50 million years scenario) does not lead to $>800^{\circ} \mathrm{C}$ temperatures, but instead there is a $600-800^{\circ} \mathrm{C}$ temperature range, more appropriate to amphibolite facies metamorphism. At these lower crustal temperatures, dehydration-melting reactions causing granulite facies metamorphism are unlikely. This slow scenario is compatible for crustal accretion in the Itsaq Gneiss Complex, because zircon geochronology shows that its tonalite components were emplaced episodically from c. 3870 to $3660 \mathrm{Ma}$, with 10 to 40 million-year interludes between each batch (Fig. 6).

\section{Discussion}

Switchover from IAB to tonalite and quartz-diorite magmatism during crustal accretion: Modern and Eoarchaean perspectives

Convergent plate boundaries and hence accretionary orogens tend to form where there was the greatest lateral density contrast in the crust, leading to one crustal segment (less dense) to be conserved and to override another (more dense) one that is destroyed. Initiation of 
destruction of the crust on one side of the boundary takes place by it foundering into the mantle. This causes rapid extension of the conserved upper plate into the void, coupled with high heat flow as asthenospheric mantle migrates into the extensional domain. As reviewed by numerous writers (e.g. Shervais 2001), fluid release from the destroyed crust into the hot overlying mantle wedge is the origin of island arc basalts (IAB) that characterise the juvenile stages of island arc systems/accretionary orogens. Boninites are magnesian, LIL-enriched mafic volcanic rocks that occur in the early stages of some arc systems. They are commonly attributed to higher degrees of fluxing of asthenospheric mantle wedge above a subduction zone, permitting higher degrees of melting (hence higher $\mathrm{MgO}$ content) and higher LIL element content than IAB. There is clear evidence that boninites and IAB can be erupted together early in the life of arc systems (Haraguchi \& Ishii, 2007).

If later in the life of a modern arc system, the crust being destroyed by subduction gets younger, it will be hotter due to more residual mid ocean ridge heat. In which case, if that crust is $<20$ million years old, it will start to melt (in the stability field of eclogite or high pressure granulite) before it can release a LIL-bearing hydrous fluid into the overlying asthenospheric mantle wedge, to initiate melting there instead (Martin 1986). This scenario of melting of the destroyed/subducted slab leads to adakite magmas of accretionary orogens - with their characteristic geochemical signatures of melting of hydrous mafic rocks under high-pressure conditions, leaving garnet as a residual phase (e.g. Smithies \& Champion 2000; Martin et al. 2005). Many researchers have in general terms likened the composition and genesis of adakites and Archaean tonalites, thereby proposing that tonalites formed at ancient convergent plate boundaries in accretionary orogens (summary by Martin et al. 2005).

In the Itsaq Gneiss Complex, crustal accretion probably occurred in several cycles (Fig. 6). Earliest rocks are always sequences dominated by amphibolites with IAB-like \pm boninitelike chemistries (e.g. Polat \& Hofmann 2003). Although in detail the chemistry of these rocks differ from their modern analogues (e.g., Jenner 2007), overall the similarities are much more striking than the differences, and it is a reasonable interpretation that they formed early in the development of ancient convergent plate boundaries (e.g. Polat \& Hofmann 2003). The early IAB-dominated sequences are then always intruded by much larger volumes of tonalite - formed by melting of mafic crust at high pressure. This is 
because in the hotter early Earth, very soon after a destructive plate boundary initiated, hotter "oceanic" crust was being destroyed at the boundary. This meant that in the Eoarchaean, IAB \pm boninite magmatism always soon switched over to voluminous tonalite magmatism. Although the importance of the tonalite component in Eoarchaean crustal accretion has long been recognised (Moorbath 1975; McGregor 1979; Nutman et al. 1999; Steenfelt et al. 2005), it is only in recent years that robust evidence for Eoarchaean IAB \pm boninite associations has been presented (e.g. Polat et al. 2002; Polat \& Hoffman 2003; Cates \& Mojzsis 2006; Jenner et al. 2006; Jenner 2007).

\section{Episodic Eoarchaean crustal accretion - Greenland}

The Itsaq Gneiss Complex contains associations of mafic rocks of broadly IAB and boninitic affinity, that are intruded by tonalite \pm quartz-diorite whose $\mathrm{Sr}, \mathrm{Nd}$ and $\mathrm{Hf}$ isotopic signatures indicate they represent new additions to the crust. Thus the Itsaq Gneiss Complex is dominated by both mafic and felsic rocks that are widely interpreted to form by hydrous melting at destructive plate boundaries. We would also propose that the Itsaq Gneiss Complex shows repeated cycles of crustal accretion of this mode, at c. $3850 \mathrm{Ma}$, $3800 \mathrm{Ma}$, maybe $3760 \mathrm{Ma}, 3700 \mathrm{Ma}$ and c. $3660 \mathrm{Ma}$, although we acknowledge that some dispute our geochronological interpretations upon which this conclusion is based (e.g. Whitehouse et al. 1999; Whitehouse \& Kamber 2005).

Given that the Itsaq Gneiss Complex consists of a small remaining fragment of a once much larger crustal accretion complex, it is impossible to reconstruct details concerning crustal architecture and palaeo-geography during accretion (in this respect we beg to differ with the synthesis for the Itsaq Gneiss Complex of Komiya et al. 1999). However, two points are noteworthy.

First, the presence of upper mantle peridotite slivers (Nutman et al. 1996, Friend et al. 2002) and high-MgO quartz-diorites (data in McGregor 1979; Nutman et al. 1999, this paper) in the Itsaq Gneiss Complex place some constraints. Thus, upper mantle peridotite slivers tectonically intercalated with mafic crustal rocks at the time of tonalite emplacement rule out a model for ancient convergent plate boundaries as a crustal sagging/ductile flow domain driven by an eclogitised root, which then melted to produce tonalite. This rules out the least uniformitarian geometry for ancient convergent plate boundaries. Likewise, the presence of the high-MgO quartz-diorites coeval with several 
generations of tonalite (Fig. 9) indicates that subordinate melting of metasomatised mantle occurred simultaneously with the tonalites whose origin involved slab melting. This could have occurred in the high pressure root of tectonically imbricated mafic crustal rocks and upper mantle slivers (obduction model of De Wit 1998) or in the context of more uniformitarian shallow subduction, with a small amount of upper mantle trapped between the conserved and destroyed crustal plates (models discussed by Smithies \& Champion 2000).

Second, certain ages of Itsaq Gneiss Complex tonalite are generally found in closer association than with others. Thus, parts of the Færingehavn terrane show an association of c. 3850 and 3750 Ma TTG, other parts around Amiitsoq only 3660 TTG occur, whereas in the northern Isukasia terrane, extensive domains of $c$. 3800 and 3700 Ma TTG seem to have been tectonically juxtaposed in the Eoarchaean (Figs. 1, 4). Thus it is quite possible that the Itsaq Gneiss Complex consists of several crustal accretion complexes formed at different convergent plate boundaries, which were later docked together in a collisional orogeny.

Collisional orogeny and the end of Itsaq Gneiss Complex Eoarchaean crustal accretion (3660 Ma)

In the Itsaq Gneiss Complex, a c. 200 million year history (>3850 to $3660 \mathrm{Ma}$ ) of crustal accretion marked by suites of IAB-like mafic rocks invaded by voluminous tonalites with lesser amounts of quartz-diorites finished at c. 3660 Ma (Friend \& Nutman 2005a). All students of the Itsaq Gneiss Complex agree that 3660-3600 Ma was a time of major tectonothermal activity in the complex, but there are differences in interpretation (e.g. Kamber et al. 1997 versus Friend \& Nutman 2005a).

Friend \& Nutman (2005a) proposed that following 3850-3690 Ma juvenile crustal accretion events, the evolution of the Itsaq Gneiss Complex continued with numerous crustal-reworking events between 3660 and 3550 Ma. Examples of these events are: (1) intrusion of several generations of geochemically diverse granites (sensu stricto), monzonites, and subordinate ferro-gabbros and ferro-diorites; (2) superimposed, multiple episodes of amphibolite to granulite facies metamorphism; (3) part of the complex around Amiitsoq and the hills to the north contains the youngest tonalitic gneisses at $c$. $3660 \mathrm{Ma}$, indistinguishable in age from the oldest recognized granites (sensu stricto) elsewhere; and 
(4) the hills north of Amiitsoq also contain deformed remnants of volcano-sedimentary basins that were still being filled between 3650 and $3600 \mathrm{Ma}$ (from dating youngest detrital zircons) and that had been inverted and metamorphosed by c. $3570 \mathrm{Ma}$ (dating of oldest in situ metamorphic overgrowths). These 3670-3550 Ma events are interpreted as reflecting a complex orogen (tentatively collisional and/or strike slip) superimposed on the products of the earlier (3850-3690 Ma) juvenile crustal accretion regimes. However Kamber et al. (1997) using the whole rock $\mathrm{Pb}$ isotopic compositions of regional collections of orthogneisses ranging from granitic to dioritic in composition, have regarded this period to embrace important crustal accretion events as well, essentially coeval with crustal reworking.

The large amount of zircon geochronology integrated with field studies from the Itsaq gneiss complex indicates that Eoarchaean granulite facies metamorphism (McGregor \& Mason 1977; Griffin et al. 1980) did not occur until 3660-3600 Ma (e.g. Friend \& Nutman 2005a). This is in accord with the reappraisal of the thermal modelling integrated with zircon geochronology of the Itsaq Gneiss Complex TTG, which suggests that the "slow" tonalite overaccretion could not have been responsible for the granulite facies metamorphism. Instead, as pointed out by Friend \& Nutman (2005a), the granulite facies metamorphism in the Itsaq Gneiss Complex is most likely related to collisional/strike slip orogenic events that marked the termination of crustal accretion, when the underplating of the crust by mafic magma caused deep crustal melting, with production of variegated suites of granites, monzonites and Fe-rich mafic rocks.

\section{Source compositions of the tonalites}

A convergent plate margin / island arc setting for the Itsaq Gneiss Complex mafic rocks and the tonalites that engulf them, means that it is unlikely that the preserved mafic rocks are the same as those that melted at depth to generate the tonalites. Instead, we propose that allochthonous amphibolite units at depth were melting to give rise to the Itsaq Gneiss Complex tonalites as in modern arcs, where adakite magmas are generated from subducted mid ocean ridge basalt crust and not from mafic arc rocks they are found associated with. Thus, in the Itsaq Gneiss Complex, “disappeared” Eoarchaean mid ocean ridge basalts might be the appropriate source material for the tonalites. Scenarios of tonalite generation from an eclogite representing 30-50\% melting of a depleted mantle composition were found to be appropriate for some Itsaq Gneiss Complex TTG (Nutman et al. 1999). 


\section{Comparison of Eoarchaean crustal evolution in Greenland and China}

The geochronology and the lithological assemblage in the Itsaq Gneiss Complex are compared in Fig. 6 with the Eoarchaean geological record of the Anshan area, NE China (Liu et al. 1992; Song et al. 1996; Wan et al. 2005; Liu et al. in press). Around the city of Anshan, the amount of known Eoarchaean crust is presently only about $1 \mathrm{~km}^{2}$ at three localities. Anshan Eoarchaean crustal evolution is marked first by emplacement of c. 3800 and $3700 \mathrm{Ma}$ trondhjemites and lesser amounts of 3800 Ma quartz-diorite, with positive initial $\varepsilon_{\mathrm{Nd}}$ values (Wan et al. 2005). These are then intruded by c. 3600 Ma granitoid sheets, and variably affected by c. 3600 Ma high-grade metamorphism with migmatisation. Thus again, as in Greenland, tonalite-trondhjemite emplacement appears not to be directly responsible for granulite facies metamorphism and granite formation. Given the small amount of surviving Archaean crust in the Anshan area, it is not surprising that even less is known about the supracrustal sequences into which the tonalites-trondhjemites must have been emplaced. However, at the Baijiafen quarry locality, Liu et al. (in press) describe mafic, biotite rich schists with silica-rich layers and a zircon age of 3727 $\pm 17 \mathrm{Ma}$, which might represent a metasomatised relict of volcano-sedimentary rocks. Overall, despite the much more scanty Eoarchaean geological record in NE China compared with in Greenland, they appear to show a general similarity in evolution (Fig. 6). This suggests that the well-documented crustal accretion processes in the Itsaq Gneiss Complex of Greenland are not unique, and might be more broadly applicable to the early Earth.

\section{Conclusions}

(1) Eoarchaean accretion, exemplified by the geological record in the Itsaq Gneiss Complex, started with formation of volcano-sedimentary sequences dominated by amphibolites with IAB-like \pm boninite-like geochemistry, with associated chemical sediments, particularly chert and BIF. They are interpreted as juvenile arc assemblages, whose mafic volcanic components were formed by fluxing of a mantle wedge by fluids derived from destroyed (“subducted”) mafic crust at convergent plate boundaries.

(2) Tonalites that are the dominant rocks in Eoarchaean terranes intrude the earlier IABdominated sequences. This occurred when hot (young) oceanic mafic crust was being subducted - causing melting within it at high pressures (residual garnet). Because of the generally hotter state of the Eoarchaean Earth, convergent plate boundary magmatism always ended-up being dominated by tonalitic compositions. 
(3) Both the dominant mafic and felsic components of Eoarchaean Itsaq Gneiss Complex have chemical signatures resembling igneous suites currently forming at some modern convergent plate boundaries. This supports thirty-year-old notions that ancient crustal accretion took place in settings with some similarities to modern convergent plate boundaries.

(4) Although a convergent plate boundary setting is preferred for the origin of the juvenile crustal accretion components in the Itsaq Gneiss Complex, little of the complex is preserved, and most was strongly modified in later tectonothermal events. However, models for the geometry and dynamics of these boundaries must be able to explain the presence of slivers of upper mantle peridotite tectonically intercalated with crustal rocks during accretion, and that there are small volumes of high-MgO quartz diorites that are coeval with the voluminous tonalites.

This research on the Itsaq Gneiss Complex was supported by NERC grant NER/A/S/1999/00024 and ARC grant DP0342798. Research on Eoarchaean crustal evolution in the Anshan area was support by the Key Programs of the Ministry of Land and Resources of China (1212010711815, 1212010561608). The paper is published with the permission of the Director of the Geological Survey of Denmark and Greenland.

\section{References}

ALLAART, J.H., 1976. The pre-3760 m.y. old supracrustal rocks of the Isua area, central West Greenland, and the associated occurrence of quartz-banded ironstone. In: WINDLEY, B.F. (ed), The Early History of the Earth. Wiley, London, pp. 177-189. APPEL, P.W.U., FEDO, C.M., MOORBATH, S. \& MYERS, J.S., 1998. Recognisable primary volcanic and sedimentary features in a low-strain domain of the highly deformed, oldest-known (ca. 3.7-3.8 Gyr) greenstone belt, Isua, Greenland. Terra Nova 10, 5762.

ARTH, J.G. \& HANSON, G.N., 1975. Geochemistry and origin of the Early Precambrian crust of north-eastern Minnesota. Geochimica et Cosmochim Acta, 39, 325-362.

BAADSGAARD, H., 1973. U-Th-Pb dates on zircons from the early Precambrian Amîtsoq gneisses, Godthaab district, West Greenland. Earth and Planetary Science Letters, 19, 22-28.

BAAdsgaArd, H., Nutman, A.P., Bridgwater, D., McGregor, V.R., Rosing, M. \& ALLAART, J.H., 1984. The zircon geochronology of the Akilia association and the 
Isua supracrustal belt, West Greenland. Earth and Planetary Science Letters, 68, 221228.

BAADSGAARD, H., NutMAN, A.P. \& BRIDGWATER, D., 1986. Geochronology and isotope geochemistry of the early Archaean Amîtsoq gneisses of the Isukasia area, southern West Greenland. Geochimica et Cosmochimica Acta, 50, 2173-2183.

BennetT, V.C., NutMan, A.P. \& McCulLOCH, M.T., 1993. Nd isotopic evidence for transient, highly depleted mantle reservoirs in the early history of the Earth. Earth and Planetary Science Letters, 119, 299-317.

BEnNETT, V.C., NuTMAn, A.P. \& EsAT, T.M., 2003. Constraints on mantle evolution and differentiation from ${ }^{187} \mathrm{Os} /{ }^{188}$ Os isotopic compositions of Archaean ultramafic rocks from southern West Greenland (3.8 Ga) and Western Australia (3.45 Ga). Geochimica et Cosmochimica Acta, 66, 2615-2630.

Black, L.P., Gale, N.H., MoOrbath, S., PANKhurst, R.J. \& McGregor, V.R., 1971. Isotopic dating of very early Precambrian amphibolite facies gneisses from the Godthåb district, West Greenland. Earth and Planetary Science Letters, 12, 245-259.

Bohlar, R., Kamber, B.S., MoOrbath, S., Fedo, C.M. \& Whitehouse, M.J., 2004. Characterisation of early Archaean chemical sediments by trace lement signatures. Earth and Planetary Science Letters, 222, 43-60.

BRIDGWATER, D. \& McGREgOR, V.R., 1974. Field work on the very early Precambrian rocks of the Isua area, southern West Greenland. Rapport Grønlands Geologiske Undersøgelse, 65, 49-54.

BROWN, G.C. \& FYFFE, W.S. 1970. Production of granitic melts during ultrametamorphism. Contributions to Mineralogy and Petrology, 28, 310-318.

CAlvert, A.J., SAWYER, E.W., DAVIS, W.J. \& LudDEN, J.N. 1995. Archaean subduction inferred from seismic images of a mantle suture in the Superior Province. Nature, 375, 670-673.

CATES, N.L. \& MoJZSIS, S.J., 2006. Chemical and isotopic evidence for widespread Eoarchean metasedimentary enclaves in southern West Greenland. Geochimica et Cosmochimica Acta, 70, 4229-4257.

CHADWICK, B. \& CREWE, M.A., 1986. Chromite in the early Archaean Akilia association (c. 3,800 m.y.), Ivîsartoq region, inner Godthåbsfjord, southern West Greenland. Economic Geology, 81, 184-191.

COMPSTON, W., KinNY, P.D., WiLliams, I.S., Foster, J.J., 1986. The age and lead loss behaviour of zircons from the Isua supracrustal belt as determined by ion microprobe. Earth and Planetary Science Letters, 80, 71-81.

CROWLEY, J.L. 2002. Testing the model of late Archean terrane accretion in southern West Greenland: a comparison of timing of geological events across the Qarliit Nunaat fault, Buksefjorden region. Precambrian Research, 116, 57-79. 
CROWLEY, J.L., 2003. U-Pb geochronology of 3810-3630 Ma granitoid rocks south of the Isua greenstone belt, southern West Greenland. Precambrian Research, 126, 235257.

Crowley, J.L., Myers, J.S. \& DunNing, G.R., 2002. The timing and nature of multiple 3700-3600 Ma tectonic events in granitoid rocks north of the Isua greenstone belt, southern West Greenland. Geological Society of America Bulletin, 114, 1311-1325.

Dauphas, N., van Zuilen, M., Wadhwa, M., Davis, A.M., Martey, B. \& JANney, P.E., 2004. Clues from Fe isotope variations on the origin of earlty Archean BIFs from Greenland. Science, 302, 2077-2080.

DE WIT, M.J. 1998. On Archean granites, greenstones, cratons and tectonics: does the evidence demand a verdict? Precambrian Research, 91, 181-226.

DYMEK, R.F. \& KLEIN, C., 1988. Chemistry, petrology and origin of banded ironformation lithologies from the 3800 Ma Isua supracrustal belt, West Greenland. Precambrian Research, 37, 247-302

FRIEND, C.R.L. \& NUTMAN, A.P. 2005a. Complex 3670-3500 Ma orogenic episodes superimposed on juvenile crust accreted between 3850-3690 Ma, Itsaq Gneiss Complex, southern West Greenland. Journal of Geology, 113, 375-398.

FRIEND, C.R.L. \& NUTMAN, A.P., 2005b. New pieces to the Archaean terrane jigsaw puzzle in the Nuuk region, southern West Greenland: Steps in transforming a simple insight into a complex regional tectonothermal model. Journal of the Geological Society of London, 162, 147-163.

FRIEND, C.R.L., NUTMAN, A.P. \& McGREGOR, V.R., 1988. Late Archaean terrane accretion in the Godthåb region, southern West Greenland. Nature, 335, 535-538.

FRIEND, C.R.L., BENNETT, V.C. \& NUTMAN, A.P. (2002). Abyssal peridotites >3,800 Ma from southern West Greenland: field relationships, petrography, geochronology, whole-rock and mineral chemistry of dunite and harzburgite inclusions in the Itsaq Gneiss Complex. Contributions to Mineralogy and Petrology, 143, 71-92.

Furnes, H., de Wit, M., Staudigel, H., Rosing, M. \& Muehlenbachs, K., 2007. Science, 215, 1704-1707.

Griffin, W.L., McGregor, V.R., NutMAn, A.P., TAYlOR, P.N. \& BRIDGWATER, D., 1980. Early Archaean granulite-facies metamorphism south of Ameralik. Earth and Planetary Science Letters, 50, 59-74.

GROVE, T.L. \& BAKER, M.B., 1983. Effects of melt density on magma mixing in calcalkaline series magmas. Nature, 305, 5933.

HAMilton, P.J., O’NiONS, R.K., EVEnSEN, N.H., BRIDGWATER, D. \& AllAART, J.H., 1978. Sm-Nd isotopic investigations of Isua supracrustals and implications for mantle evolution. Nature, 272, 41-43. 
HANMER, S. \& GREENE, D.C., 2002. A modern structural regime in the Paleoarchean ( 3.64 Ga); Isua Greenstone Belt, southern West Greenland. Tectonophysics, 346, 201-222.

HARAGUCHI, S. \& ISHII, T. 2007. Simultaneous boninitic and arc-tholeiitic volcanisms in the Izu forearc region during early arc volcanism, based on ODP Leg 125 Site 786. Contributions to Mineralogy and Petrology, 153, 509-531.

HofmanN, A.W., 1988. Chemical differentiation of the Earth: the relationships between mantle, continental crust, and oceanic crust. Earth and Planetary Science Letters, 90, 297-314.

JenneR, F., 2007. Geochemistry and Petrogenesis of Archaean Mafic and Ultramafic Rocks, southern West Greenland. Australian National University, PhD thesis, 275 pp.

JENNER, F., BENNETT, V.C. \& NUTMAN, A.P., 2006. 3.8 Ga arc related basalts from Southwest Greenland. 2006 Goldschmidt Conference Abstracts.

KAMBER, B.S. \& MOORBATH, M, 1998. Initial Pb of the Amîtsoq gneiss revisited: implication for the timing of early Archaean crustal evolution in West Greenland. Chemical Geology, 150, 19-41.

KAMBER, B.S., WhitehOUSE, M.J., BOLHAR, R. \& MOORBATH, S., 2005. Volcanic resurfacing and the early terrestrial crust: Zircon $\mathrm{U}-\mathrm{Pb}$ and REE constraints from the Isua Greenstone Belt, southern West Greenland. Earth and Planetary Science Letters, 240, 276-290.

Komiya, T., Maruyama, S., Masuda, T, APPel, P.W.U. \& NOHDA, S., 1999. The 3.83.7 Ga plate tectonics on the Earth; Field evidence from the Isua accretionary complex, West Greenland. Journal of Geology, 107, 515-554.

LiU, D.Y., NUTMAN, A.P., COMPSTON, W., WU, J.S. \& SHEN, Q.H., 1992. Remnants of $\geq 3800$ Ma crust in the Chinese part of the Sino-Korean craton. Geology, 20, 339-342.

MARTIN, H., 1986. Effect of steeper Archaean geothermal gradient on geochemistry of subduction-zone magmas. Geology, 14, 753-756.

MARTIN, H., 1999. Adakitic magmas: modern analogues of Archaean granitoids. Lithos, 46, 411-429.

MARTIN, H. \& MOYEN, J.-F., 2002. Secular changes in tonalite-trondhjemite-granodiorite composition as markers of the progressive cooling of Earth. Geology, 30, 319-322.

MARTin, H. Smithies, R.H., RAPP, R., MOYEn, J.-F. \& ChAMPION, D., 2005. An overview of adakite, tonalite-trondhjemite-granodiorite (TTG), and sanukitoid: relationships and some implications for crustal evolution. Lithos, 79, 1-24.

McGREGOR, V.R., 1973. The early Precambrian gneisses of the Godthåb district, West Greenland. Philosophical Transactions of the Royal Society of London, A273, 343358.

McGREGOR, V.R., 1979. Archean gray gneisses and the origin of continental crust: evidence form the Godthåb region, West Greenland. In: BARKER, F. (ed), 
Trondhjemites, dacites and related rocks. Developments in Petrology, vol. 6.

Elsevier, Amsterdam, 169-204.

McGregOR, V.R. \& MASON, B., 1977. Petrogenesis and geochemistry of metabasaltic and metasedimentary enclaves in the Amîtsoq gneisses, West Greenland. American Mineralogist, 62, 887-904.

McGregor, V.R., FrIEND, C.R.L. \& NuTMAn, A.P., 1991. The late Archaean mobile belt through Godthåbsfjord, southern West Greenland: a continent-continent collision zone? Bulletin of the Geological Society of Denmark, 39, 179-197.

Michard-VitraC, A., LANCELOT, J., Allegre, C.J. \& MoOrbath, S., 1977. U-Pb ages on single zircons from early Precambrian rocks of West Greenland and the Minnesota River Valley. Earth and Planetary Science Letters, 35, 449-453.

MOJZSIS, S.J. \& HARRISON, T.M., 2002. Establishment of a 3.83-Ga magmatic age for the Akilia tonalite (southern West Greenland). Earth and Planetary Science Letters, 202, 563-576.

MoORBATH, S. 1975. Evolution of Precambrian crust from strontium isotopic evidence. Nature, 254, 395-398.

MoOrbath, S., O’NiOns, R.K., PANKhuRst, R.J., GALE, N.H. \& McGreGOR, V.R., 1972. Further rubidium-strontium age determinations on the very early Precambrian rocks of the Godthåb district: West Greenland. Nature, 240, 78-82.

Moorbath, S., AllaART, J.H., Bridgwater, D. \& McGregor, V.R., 1977. Rb-Sr ages of early Archaean supracrustal rocks and Amîtsoq gneisses at Isua. Nature, 270, 4345.

MYERS, J.S., 2001. Protoliths of the 3.8-3.7 Ga Isua greenstone belt, West Greenland. Precambrian Research, 105, 129-141.

NUTMAN, A.P., 1984. Early Archaean crustal evolution of the Isukasia area, southern West Greenland. In: KRÖNER, A. \& GreILING, R. (eds) Precambrian Tectonics Illustrated. Stuttgart, E. Schweitzerbart'sche Verlagsbuchhandlung.

NuTMAn, A.P., 2006. Antiquity of the Oceans and Continents. Elements, 2, 223-227.

NuTMAN, A.P. \& BRIDGWATER, D., 1986. Early Archaean Amîtsoq tonalites and granites from the Isukasia area, southern West Greenland: Development of the oldest-known sial. Contributions to Mineralogy and Petrology, 94, 137-148.

NuTMAN, A.P. \& COLLERSON, K.D., 1991. Very early Archean crustal-accretion complexes preserved in the North Atlantic Craton. Geology, 19, 791-794.

NuTMAn, A.P., BRIDGWATER, D. \& FRYER, B, 1984a. The iron rich suite from the Amîtsoq gneisses of southern West Greenland: Early Archaean plutonic rocks of mixed crustal and mantle origin. Contributions to Mineralogy and Petrology, 87, 2434.

Nutman, A.P., AllaART, J.H., BridgWATER, D. DimRoth, E. \& Rosing, M.T., 1984b. Stratigraphic and geochemical evidence for the depositional environment of the early 
Archaean Isua supracrustal belt, southern West Greenland. Precambrian Research, 25, 365-396.

NutMAn, A.P., Friend, C.R.L., KinNY, P.D. \& McGREgOR, V.R., 1993. Anatomy of an Early Archaean gneiss complex: 3900 to 3600 Ma crustal evolution in southern West Greenland. Geology, 21, 415-418.

Nutman, A.P., McGregor, V.R., Friend, C.R.L., BennetT, V.C. \& KinnY, P.D., 1996. The Itsaq Gneiss Complex of southern West Greenland; the world's most extensive record of early crustal evolution (3900-3600 Ma). Precambrian Research, 78, 1-39.

Nutman, A.P., BEnNetT, V.C., Friend, C.R.L. \& Rosing, M.T. 1997. 3710 and $\geq 3790$ Ma volcanic sequences in the Isua (Greenland) supracrustal belt; structural and $\mathrm{Nd}$ isotope implications. Chemical Geology, 141, 271-287.

Nutman, A.P., BennetT, V.C., Friend, C.R.L. \& NoRMAn, M., 1999. Meta-igneous (non-gneissic) tonalites and quartz-diorites from an extensive ca. 3800 Ma terrain south of the Isua supracrustal belt, southern West Greenland: constraints on early crust formation. Contributions to Mineralogy and Petrology, 137, 364-388.

Nutman, A.P., Friend, C.R.L., BennetT, V.C. \& McGregor, V.R., 2000. The early Archaean Itsaq Gneiss Complex of southern West Greenland: The importance of field observations in interpreting dates and isotopic data constraining early terrestrial evolution. Geochimica et Cosmochimica Acta, 64, 3035-3060.

Nutman, A.P., McGregor, V.R., Shiraishi, K., Friend, C.R.L., BenNEtT, V.C. \& KINNY, P.D., 2002a. $\geq 3850$ Ma BIF and mafic inclusions in the early Archaean Itsaq Gneiss Complex around Akilia, southern West Greenland? The difficulties of precise dating of zircon-free protoliths in migmatites. Precambrian Research, 117, 185-224.

NuTMAN, A.P., FRIEND, C.R.L. \& BENNETT, V.C., 2002b. Evidence for 3650-3600 Ma assembly of the northern end of the Itsaq Gneiss Complex, Greenland: Implication for early Archean tectonics. Tectonics, 21, article 5

NuTMAN, A.P., FRIEND, C.R.L., BARKER, S.S. \& McGREgOR, V.R., 2004, Inventory and assessment of Palaeoarchaean gneiss terrains and detrital zircons in southern West Greenland. Precambrian Research, 135, 281-314.

Nutman, A.P., BennetT, V.C., Friend, C.R.L., Horie, K. \& Hidaka, H., in press a. $\sim 3850$ Ma tonalites in the Nuuk region, Greenland: Geochemistry and their reworking within an Eoarchaean gneiss complex. Contributions to Mineralogy and Petrology, (galley proofs corrected and sent back to journal).

NuTMAN, A.P., FRIEND, C.R.L., HORIE, H. \& HIDAKA, H. in press b. Construction of pre3600 Ma crust at convergent plate boundaries, exemplified by the Itsaq Gneiss Complex of southern West Greenland. In: VAn KRANENDONK, M.J. (ed) The early Earth. Elsevier, (receiving galley proofs in late June). 
O’NiONS, R.K. \& PANKHURST, R.J., 1974. Rare-earth element distribution in Archaean gneisses and anorthosites, Godthåb area, West Greenland. Earth and Planetary Science Letters, 22, 328-338.

POLAT, A. \& HofMANN, A.W., 2003. Alteration and geochemical patterns in the 3.7-3.8 Ga Isua greenstone belt, West Greenland. Precambrian Research, 126, 197-218.

Polat, A., Hofmann, A.W. \& Rosing, M.T., 2002. Boninite-like volcanic rocks in the 3.7-3.8 Ga Isua greenstone belt, West Greenland: geochemical evidence for intraoceanic subduction processes in the early Earth. Chemical Geology, 184, 231-254.

RAPP, R.P. 1997. Heterogeneous source regions for Archean granitoids. In: DE WIT, M.J. \& ASHWAL, L.D. (eds) Greenstone Belts. Oxford: Oxford University Press, 267-279.

RosinG, M., 1999. ${ }^{13}$ C-depleted carbon microparticles in > 3700 Ma seafloor sedimentary rocks from Greenland. Science, 283, 674-676.

Rosing, M.T, Rose, N.M., Bridgwater, D. \& ThOMSEN, H.S., 1996. Earliest part of the Earth's stratigraphic record: A reappraisal of the $>3.7 \mathrm{Ga}$ Isua (Greenland) supracrustal sequence. Geology, 24, 43-46.

SHERVAIS, J.W. 2001. Birth, death, and resurrection: The life cycle of suprasubduction zone ophiolites. Geochemistry Geophysics Geosystems, paper number $2000 G C 000080$.

SMITHIES, R.H., 2000. The Archaean tonalite-trondhjemite-granodiorite (TTG) series is not an analogue of Cenozoic adakites. Earth and Planetary Science Letters, 182, 115125.

SMithiES, R.H. \& CHAMPION, D.C., 2000. The Archaean high-Mg diorite suite: Links to tonalite-trondhjemite-granodiorite magmatism and implications for early Archaean crustal growth. Journal of Petrology, 41, 1653-1671.

SolvANG, M. 1999. An investigation of metavolcanic rocks from the eastern part of the Isua greenstone belt, Western Greenland. Geological Survey of Denmark and Greenland (GEUS) Internal Report, Copenhagen, Denmark, 62 pages.

SONG, B., NUTMAN, A.P., LIU, D.Y. \& WU, J.S., 1996. 3800 to 2500 Ma crustal evolution in the Anshan area of Liaoning province, northeastern China. Precambrian Research, 78, 79-94.

Steenfelt, A., Garde, A.A., Moyen, J.-F., 2005. Mantle wedge involvement in the petrogenesis of Archaean grey gneisses in West Greenland. Lithos, 79, 207-228.

WAN, Y., LiU, D.Y., SONG, B., JiASHAN, W., CHONGHUI, Y., ZONGQING, Z. \& YUANSHENG, G., 2005. Geochemical and Nd isotopic compositions of 3.8 Ga metaquartz dioritic and trondhjemitic rocks from the Anshan area and their geological significance. Journal of Asian Earth Sciences, 24, 563-575.

WELLS, P.R.A., 1980. Thermal models for the magmatic accretion and subsequent metamorphism of continental crust. Earth and Planetary Science Letters, 46, 253265. 
Whitehouse, M.J. \& KAMBER, B.S., 2005. Assigning dates to thin gneissic veins in highgrade metamorphic terranes: A cautionary tale from Akilia, southwest Greenland. Journal of Petrology, 46, 291-318.

Whitehouse, M.J., KamBer, B.S., MoORBATH, S., 1999. Age significance of U-Th-Pb zircon data from early Archaean rocks of west Greenland - a reassessment based on combined ion-microprobe and imaging studies. Chemical Geology, 160, 201-224.

WYLLIE, P.J., WOLF, M.B., VAN DER LAAN, S.R., 1997. Conditions for the formation of tonalites and trondhjemites. In: DE WIT, M.J. \& ASHWAL, L.D. (eds) Greenstone Belts. Oxford: Oxford University Press, 250-266. 


\section{Table captions}

Table 1. Representative whole rock chemical analyses. Data are from Nutman \& Bridgwater (1986), Nutman et al. (1996, 1999, in press a), Polat \& Hofmann (2003), Jenner (2007) and previously unpublished data of the Geological Survey of Greenland (data of A. Nutman, and compilations of the late V.R. McGregor and the late D. Bridgwater). Lithology abbreviations in the fourth row are: layered-p = layered peridotite (from layered basic intrusions); anorth = anorthosite (from layered basic intrusions); IAB = metabasaltic amphibolite with chemical affinities with Island Arc Basalt; bon = metabasaltic amphibolite with chemically affinities with boninites; qtz-diorite $=$ quartz-diorite and trondhj $=$ trondhjemite. Age constraints in the fifth row are from SHRIMP U/Pb zircon geochronology: > $\mathrm{xxxx}$ Ma is where the minimum age for mafic or ultramafic rocks has been obtained from intrusive tonalite sheets. $\sim \mathrm{xxxx} \mathrm{Ma}$ is the likely age based on geological relationships and associated dated rocks. Other ages are direct ages on the samples for which whole rocks analyses are presented.

\section{Figure captions}

Figure 1. Geological map of the Nuuk region, displaying the Eoarchaean Itsaq Gneiss Complex, summary of SHRIMP U/Pb zircon results on TTG rocks. Localities mentioned in the text are indicated.

Figure 2. Orthogneisses of the Itsaq Gneiss Complex. (A) Typical banded grey gneiss from the Færingehavn terrane. Reconnaissance SHRIMP U/Pb zircon dating (Horie, Nutman \& Hidaka, un published data) indicates this rock contains predominantly c. $3750 \mathrm{Ma}$ palaeosome $(p)$ and $c .3650$ Ma neosome $(n)$. Due to the intimate association of components of different age caused by some in situ melting and superimposed strong polyphase Archaean deformation, such rocks are unsuitable for modern geochemical studies. (B) Intrusive relationships preserved in plutonic rocks north of the Isua supracrustal belt. Weakly deformed $c .3700$ Ma tonalites $(t)$ are first cut by a dioritic c. 3660 Ma Inaluk dyke $(d)$ and then by marginally younger (3660-3650 Ma) leucogranite sheets $(g)$. Photo courtesy of J.L. Crowley. (C) Complexities of $c$. 3800 Ma tonalites in rare low strain zone south of the Isua supracrustal belt. Isotropic biotite tonalite (it) in top left forms matrix to jumbled blocks of 
weakly foliated/banded tonalite ( $f t)$. Tonalites are cut by an amphibolitised, but undeformed Ameralik dyke (Ad) with likely age of 3500 Ma.

Figure 3. Supracrustal rocks and gabbros of the Itsaq Gneiss Complex. (A) Relict pillow structure in amphibolite with IAB chemistry in the western part of the Isua supracrustal belt. They face to the left of the picture but have been substantially flattened orthogonally to their original layering. Tops (T) and bases (B) of some pillows are indicated. Triangular domains of silica-rich interpillow hyaloclastite are locally preserved (IPH). (B) BIF from the eastern end of the Isua supracrustal belt. In the right hand side of the photograph the original sedimentary layering is preserved, but is still deformed. In the left hand side of the photograph deformation is much stronger, with transposed quartz + magnetite layering and development of a new magnetite foliation. This is the more typical state of preservation of BIF in the Itsaq Gneiss Complex. (C) Relict graded layering in a layered gabbro/anorthosite enclave, in the Færingehavn terrane. Anorthosite (an) at the bottom of the exposure has a sharp contact with overlying melagabbro $(\mathrm{mg})$, which then grades up into gabbro $(\mathrm{g})$ and leucogabbro $(l g)$. Mineralogy is now entirely metamorphic plagioclase + hornblende. There is no igneous plagioclase + pyroxenes \pm olivine preserved. An a segregation vein formed under granulite facies but now retrogressed under amphibolite facies conditions (granu vein) cuts the igneous layering.

Figure 4. Map of part of the eastern part of the Isua supracrustal belt, based on revised mapping by Nutman and Friend in 2004 and 2005. All indicated zircon age determinations without name indicated are by Nutman and co-workers (published and in press).

Figure 5. (A) Map of an area dominated by c. 3800 Ma orthogneisses, south of the Isua supracrustal belt. Based on mapping by Nutman in 1981, with revisions in 1997. (B) Map showing mantle harzburgite in tectonic contact with layered peridotites and gabbros, prior to intrusion of $c .3800$ Ma tonalites. 
Figure 6. Histograms summarising the SHRIMP zircon geochronological framework for the Itsaq Gneiss Complex of Greenland and the Eoarchaean rocks of the Anshan area, NE China.

Figure 7. Depleted mantle normalised trace-element spidergrams for selected amphibolites from the Itsaq Gneiss Complex. Data are from Polat et al. (2002), Polat \& Hofmann (2003) and Jenner (2007).

Figure 8. Al versus Mg (wt. proportion) for ultramafic rocks from the Itsaq Gneiss Complex. Homogeneous dunites and harzburgites follow the mantle trend, and have distinct compositions from layered peridotites representing cumulate components in layered gabbro complexes.

Figure 9. Geochemistry of Itsaq Gneiss Complex and Anshan area tonalites/trondhjemites and quartz-diorites. (A) $\mathrm{SiO}_{2}$ versus $\mathrm{MgO}$ (wt\%) plot, demonstrating most samples fall in the >3500 Ma field, for compositions dominated by melting of a basaltic slab (Martin et al. 2005). The coeval, volumetrically minor quartz-diorites are too magnesian to have formed by solely melting of a basaltic slab, and melting of (metasomatised) mantle must have been involved as well. These samples fall within the field of younger Archaean, and even postArchaean compositions. (B) $\mathrm{Yb}$ (ppm) versus La/Yb plot. (C) Rb (ppm) versus Sr/Y plot. Shown on it are melting models, using eclogite and garnet amphibolite sources (see text for discussion).

Figure 10. One-dimensional thermal relaxation models of overaccretion models (Wells, (1980). Figures from that paper have been reorganised for the sake of discussions in this paper. 


\section{\begin{tabular}{l|l|l|l}
\hline 2560 Ma Qôrqut \\
Granite Complex
\end{tabular}}

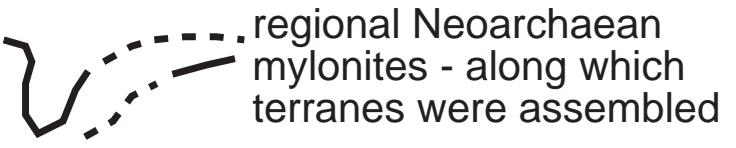
northern limit of strong

(N) Neoarchaean strain in the Isukasia terrane Neo- Meso-Archaean terranes (different ages in each terrane)

Itsaq Gneiss Complex; terranes of 3600-3900 Ma rocks. I=Isukasia terrane $\mathrm{F}=\mathrm{F}$ æringehavn terrane (only the largest units of supracrustal rocks in the Isukasia terrane are shown) Units of supracrustal rocks and gabbros (all Archaean)

SHRIMP-U/Pb zircon dating of tonalitic orthogneiss components no significant tonalite date significant 3600-3660 Ma tonalite date $3600-3660 \mathrm{Ma}$ migmatisation

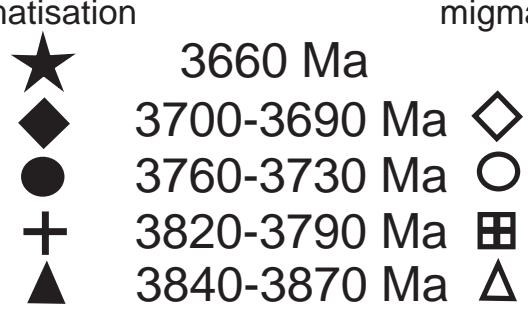

due to space restrictions - multiple samples at closely-spaced localities are not shown
Isua $50^{\circ} \mathrm{W}$
supracrustal

Fig. 4
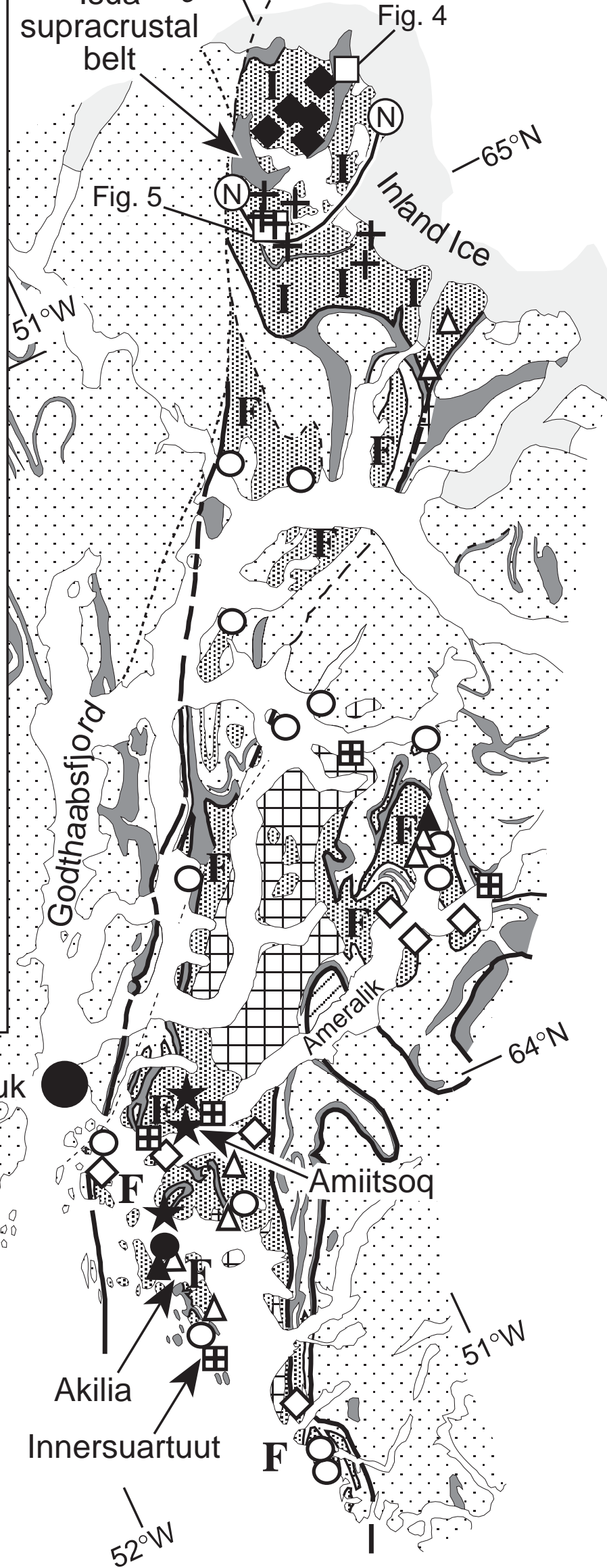
$1 N \log$

Who -36 $4 x(-x+1-10 \%$

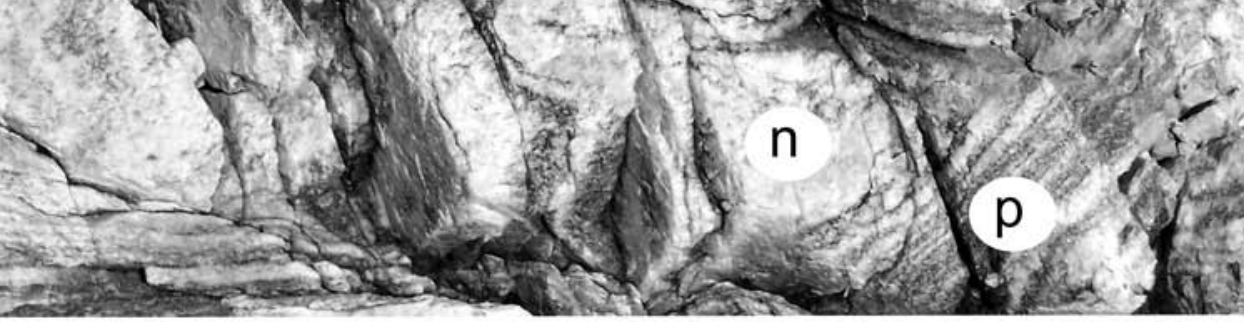

de

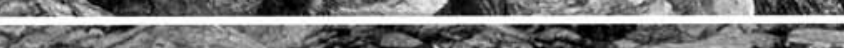

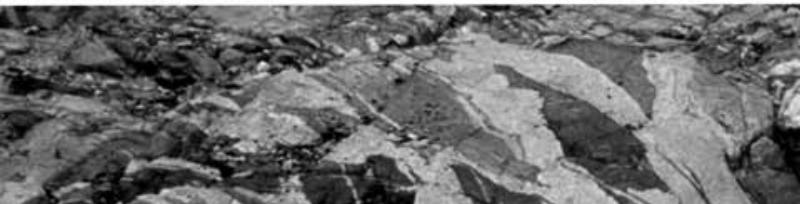

(d)

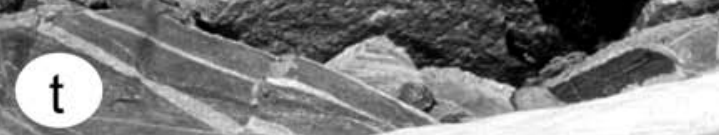

党.

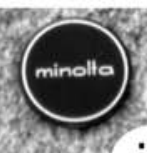
it 


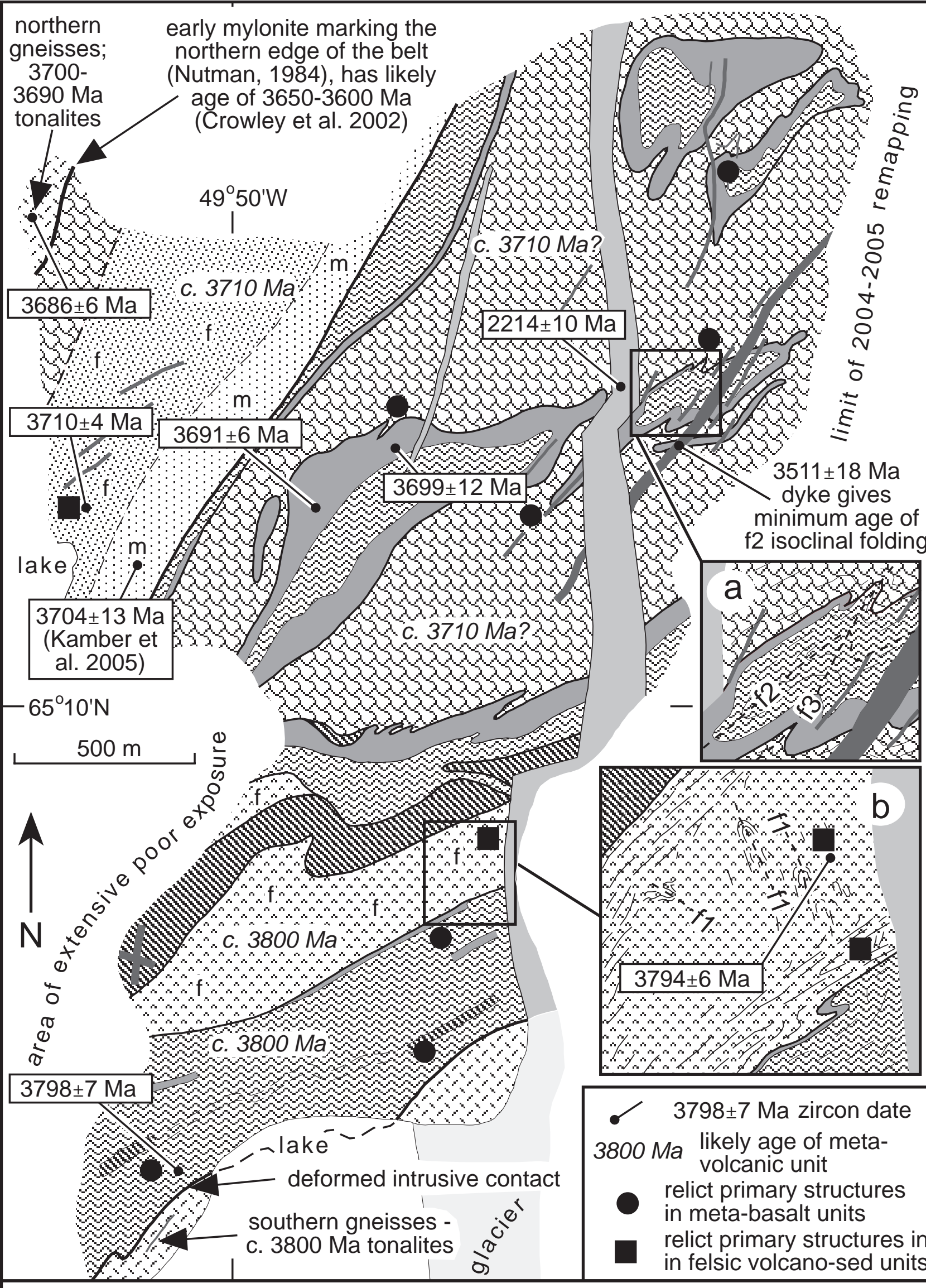

$8 \$$ "boninitic" amphibolites mostly AIB amphibolites $\left\{\begin{array}{l}\text { rare pillow structure relicts } \\ \text { show that volcanic rocks } \\ \text { are important protoliths }\end{array}\right.$

$3798 \pm 7$ Ma zircon date $3800 \mathrm{Ma}$ likely age of metavolcanic unit

relict primary structures

in meta-basalt units

relict primary structures in in felsic volcano-sed units

浱 in: felsic/mafic schists - rare volcanic structure m.] relicts show volcanic/sedimentary origin chemical sediment (includes BIF)

Eoarchaean orthogneisses

mafic dykes

$\longrightarrow$ Mesoarchaean Palaeoproterozoic ultramafic rocks 



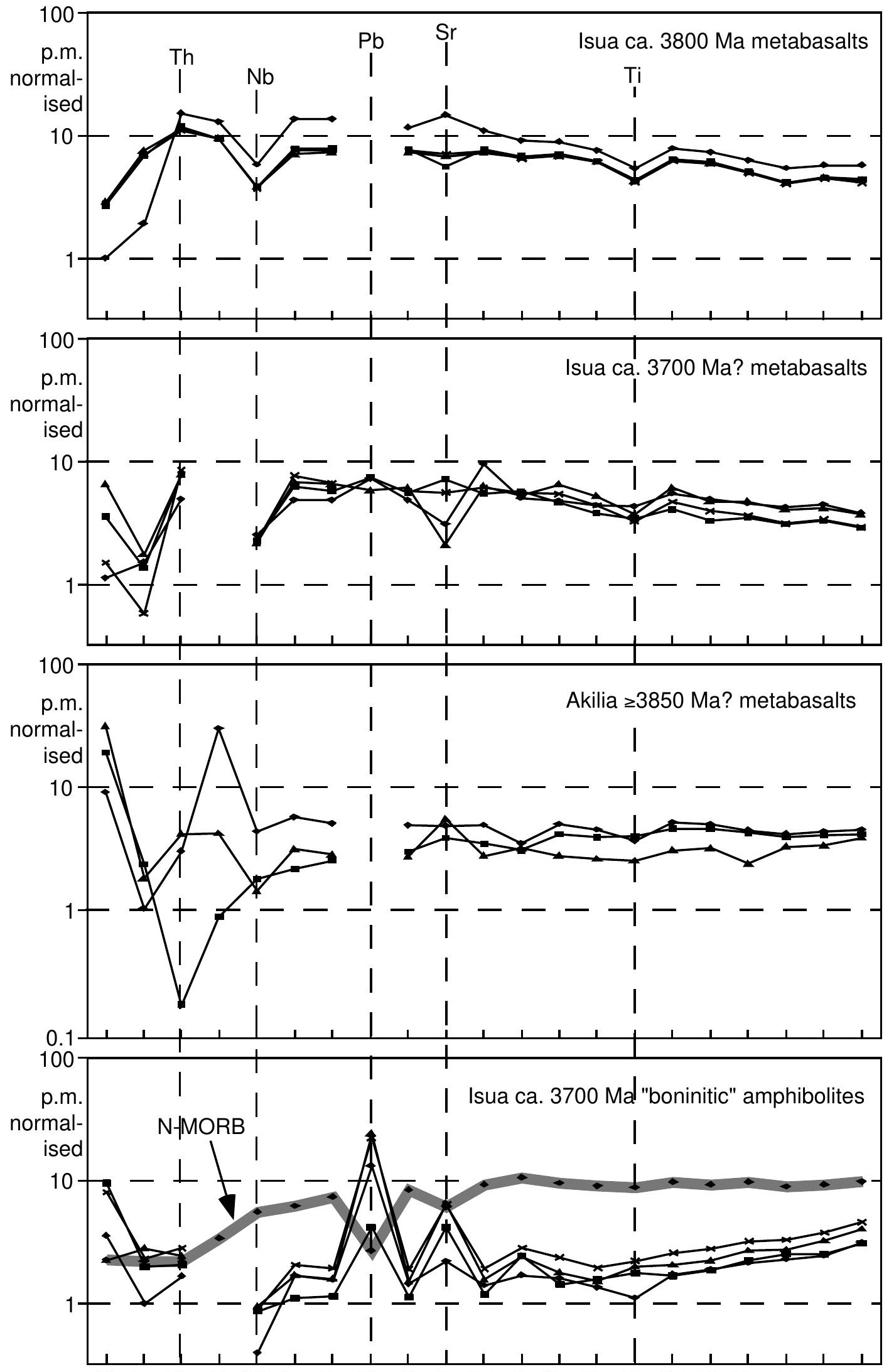

$\mathrm{Rb} \mathrm{Ba}$ Th $\mathrm{U}$ Nb La Ce Pb Pr Sr Nd Zr Sm Eu Ti Gd Tb Dy Y Ho Er 


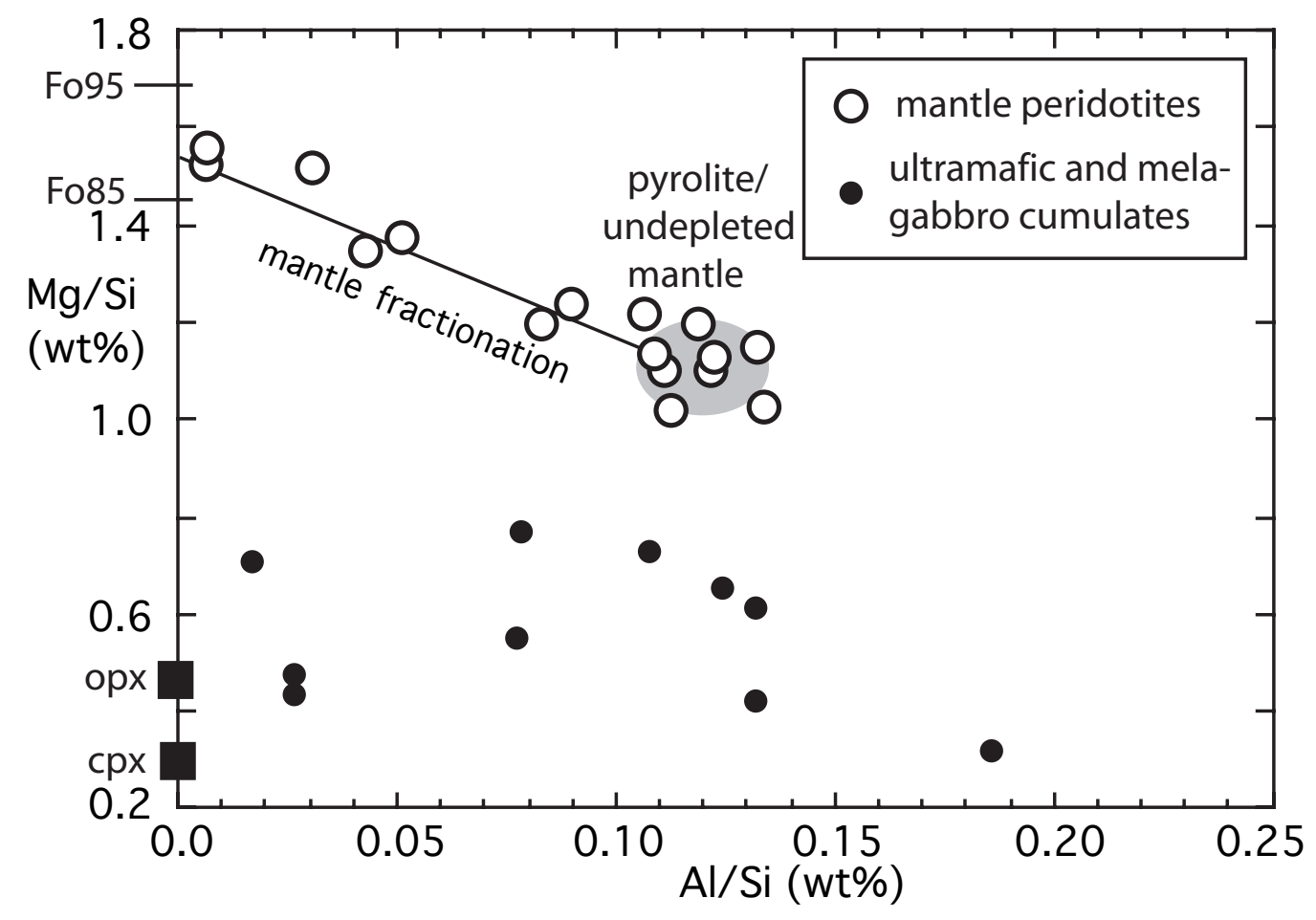



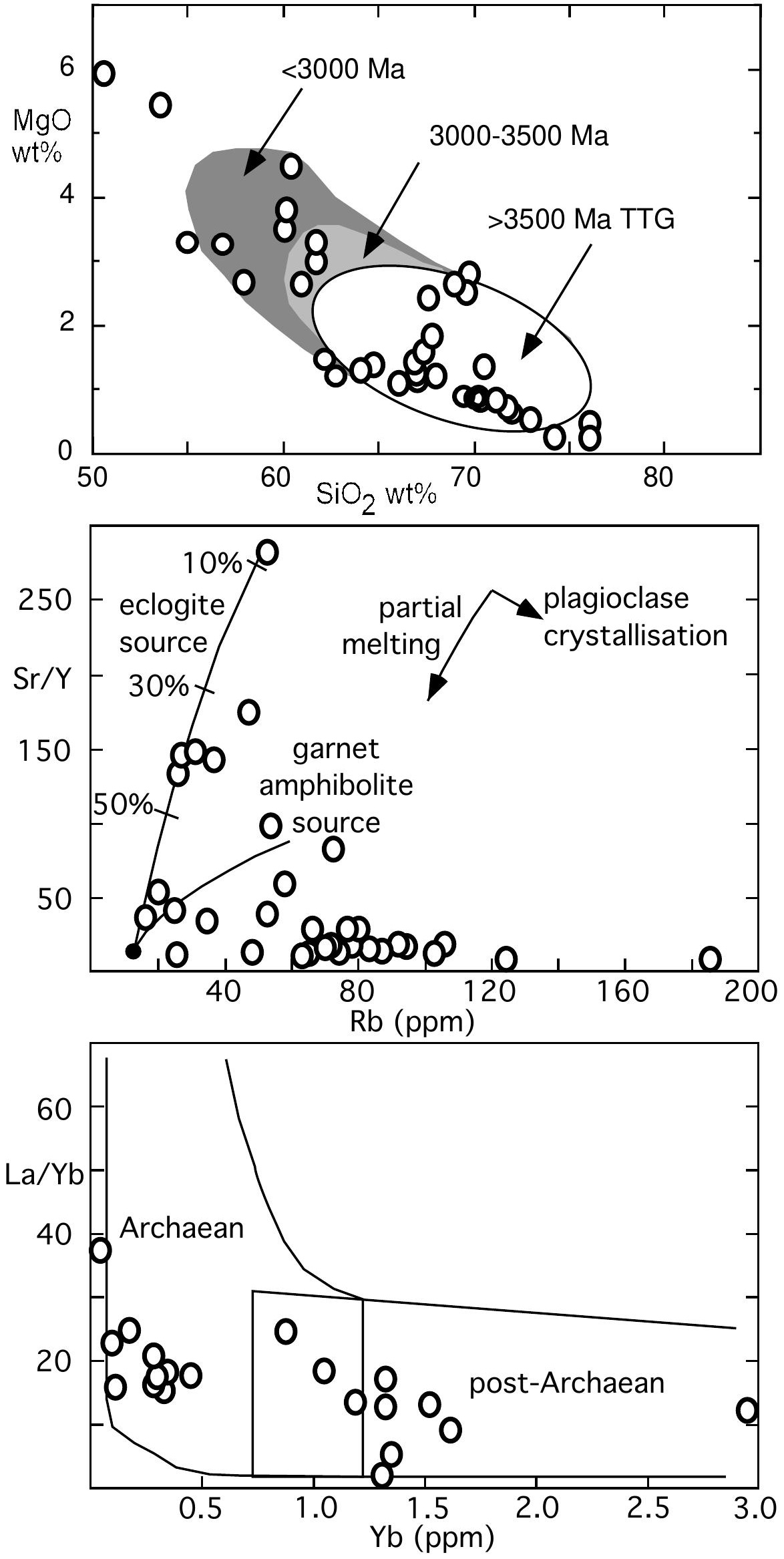


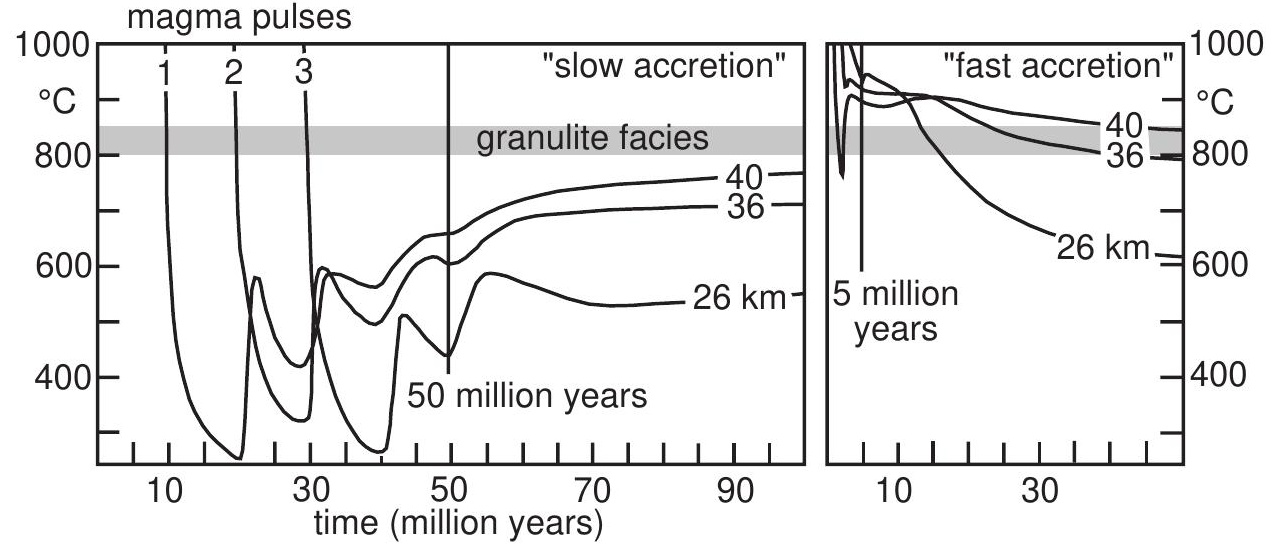




\begin{tabular}{|c|c|c|c|c|c|c|c|c|c|c|c|c|c|c|c|c|c|c|}
\hline \multirow[b]{3}{*}{ sample } & \multicolumn{18}{|c|}{ Greenland mafic and ultramafic rocks } \\
\hline & \multicolumn{7}{|c|}{$\begin{array}{|ll|}\text { mantle slivers } & \text { layered intrusions } \\
\end{array}$} & \multicolumn{11}{|c|}{ mafic volcanic rocks } \\
\hline & G93/48 & $\mathrm{G} 93 / 42$ & G93/49 & G93/71 & G03/64 & G03/62 & G91/30 & G99/33 & $\mathrm{JG03/03}$ & G91/47 & JG03/45 & JG03/46 & $\mathrm{JG} 03 / 48$ & JG03/49 & $2000-6$ & $2000-10$ & $2000-14$ & $2000-19$ \\
\hline lithology & \begin{tabular}{|l|l} 
dunite \\
\end{tabular} & harzb & layered-p & layered-p & gabbro & gabbro & anorth & IAB-Akilia & IAB-Akilia & IAB-Akilia & IAB-Isua & IAB-Isua & IAB-Isua & IAB-Isua & IAB-Isua & IAB-Isua & IAB-Isua & IAB-Isua \\
\hline age & $>3800 \mathrm{Ma}$ & $>3800 \mathrm{Ma}$ & $>3800 \mathrm{Ma}$ & $>3800 \mathrm{Ma}$ & $>3850 \mathrm{Ma}$ & $>3850 \mathrm{Ma}$ & $>3850 \mathrm{Ma}$ & $>3850 \mathrm{Ma}$ & $>3850 \mathrm{Ma}$ & $>3850 \mathrm{Ma}$ & $>3800 \mathrm{Ma}$ & $>3800 \mathrm{Ma}$ & $>3800 \mathrm{Ma}$ & $>3800 \mathrm{Ma}$ & $\sim 3700 \mathrm{Ma}$ & $\sim 3700 \mathrm{Ma}$ & $\sim 3700 \mathrm{Ma}$ & $\sim 3700 \mathrm{Ma}$ \\
\hline$\overline{\mathrm{SiO} 2}$ & 40.57 & 44.46 & 42.33 & 48.71 & 47.4 & 47.5 & 48.73 & 49.2 & 45.6 & 52.1 & 52.7 & 50.8 & 51.7 & 51.2 & 51.7 & 51.2 & 48.76 & 50.95 \\
\hline TiO2 & 0.01 & 0.1 & 0.06 & 0.23 & 0.23 & 0.25 & 0.17 & 0.69 & 0.75 & 0.48 & 0.97 & 0.78 & 0.76 & 0.75 & 0.78 & 0.62 & 0.67 & 0.59 \\
\hline $\mathrm{Al} 2 \mathrm{O} 3$ & 0.17 & 3.2 & 4.12 & 6.1 & 22.1 & 18.2 & 27.91 & 15.1 & 14.68 & 15.91 & 14.5 & 9.2 & 9.3 & 9.3 & 10.28 & 8.38 & 8.89 & 7.99 \\
\hline $\mathrm{Fe} 2 \mathrm{O} 3$ & 10.01 & 9.36 & 12.81 & 11.7 & 6.58 & 8.48 & 3.47 & 12.46 & 14.51 & 9.78 & 11.5 & 13.6 & 13 & 12.9 & 13.63 & 12.84 & 14.61 & 13.11 \\
\hline $\mathrm{FeO}$ & & & & & & & & & & & & & & & & & & \\
\hline $\mathrm{MnO}$ & 0.15 & 0.11 & 0.16 & & 0.12 & 0.16 & 0.07 & 0.29 & 0.3 & 0.13 & 0.21 & 0.22 & 0.22 & 0.22 & 0.25 & 0.19 & 0.23 & 0.17 \\
\hline $\mathrm{MgO}$ & 48.14 & 41.47 & 36.42 & 27.35 & 7.11 & 10.6 & 4.43 & 6.14 & 6.77 & 8.68 & 5.3 & 12 & 11.4 & 11.4 & 9.36 & 14.42 & 13.98 & 15.28 \\
\hline $\mathrm{CaO}$ & 0.02 & 0.15 & 3.43 & 5.51 & 13.6 & 11.3 & 13.97 & 13.79 & 14.9 & 7.97 & 8 & 10.6 & 10.6 & 10.7 & 11.4 & 10.03 & 11.39 & 10.05 \\
\hline $\mathrm{Na} 2 \mathrm{O}$ & & & 0.3 & 0.5 & 2.03 & 2.17 & 1.7 & 1.14 & 1.45 & 3.44 & 4.67 & 1.61 & 1.77 & 1.81 & 2.37 & 2.19 & 1.27 & 1.72 \\
\hline K2O & & & 0.06 & 0.11 & 0.67 & 1.43 & 0.1 & 0.35 & 0.58 & 0.57 & 0.13 & 0.16 & 0.16 & 0.16 & 0.15 & 0.07 & 0.12 & 0.05 \\
\hline P2O5 & 0.01 & & 0.01 & & 0.01 & 0.02 & 0.02 & 0.08 & 0.03 & 0.04 & 0.1 & 0.05 & 0.05 & 0.05 & 0.07 & 0.06 & 0.07 & 0.07 \\
\hline LOI & & & & & 0.04 & 0 & 1.2 & 0.55 & 0.19 & 0.72 & & & & & 2.11 & 0.98 & 1.36 & 1.03 \\
\hline $\mathrm{Cr}$ & 1286 & 2233 & 2194 & 3185 & 225 & 455 & 139 & 571 & 662 & 184 & 83 & 974 & 960 & 987 & 594 & 1621 & 1559 & 1648 \\
\hline Co & 150 & 146 & 137 & 97 & & & & & & & 37.5 & 64.8 & 63.2 & 64.6 & 57 & 80 & 82 & 81 \\
\hline $\mathrm{Ni}$ & 2697 & 2560 & 1595 & 865 & 174 & 225 & 103 & 183 & 219 & 81.2 & 70.7 & 257 & 250 & 258 & 127 & 516 & 554 & 597 \\
\hline $\mathrm{Rb}$ & & & & & 11 & 86.9 & 8.7 & 5 & 10.4 & 16.8 & 0.53 & 1.43 & 1.52 & 1.49 & 0.6 & 1.9 & 3.5 & 0.8 \\
\hline $\mathrm{Sr}$ & & & & & 108 & 74.8 & 367 & 91.8 & 73.4 & 104 & 265 & 101 & 122 & 127 & 56 & 131 & 38 & 102 \\
\hline $\mathrm{Ba}$ & & & & & 39.7 & 44.5 & 111 & 6.6 & 15 & 11.6 & 11.5 & 41 & 45.3 & 41.8 & 9.1 & 8.2 & 10.5 & 3.5 \\
\hline V & & & & & & & & 233 & 252 & 233 & & & & & 210 & 149 & 174 & 147 \\
\hline $\mathrm{Ta}$ & & & & & 0.051 & 0.036 & & 0.695 & 0.062 & 0.093 & 0.24 & 0.17 & 0.16 & 0.17 & 0.13 & 0.12 & 0.12 & 0.12 \\
\hline $\mathrm{Nb}$ & & & & & 0.739 & 0.533 & 17.8 & 2.8 & 1.17 & 0.935 & 3.54 & 2.35 & 2.33 & 2.27 & 1.54 & 1.4 & 1.33 & 1.37 \\
\hline $\mathrm{Zr}$ & & & & & 12.5 & 14 & 174 & 35.1 & 31.3 & 32.4 & 87.3 & 65.2 & 63.7 & 62.4 & 49 & 55.6 & 50.9 & 53.7 \\
\hline Th & & & & & 0.065 & 0.032 & & 0.256 & 0.015 & 0.351 & 1.22 & 0.95 & 0.92 & 0.89 & 0.4 & 0.63 & 0.63 & 0.69 \\
\hline U & & & & & 0.042 & 0.064 & & 0.615 & 0.019 & 0.089 & 0.26 & 0.19 & 0.19 & 0.19 & & 0.1 & 0.11 & 0.11 \\
\hline Y & & & & & 5.61 & 6.22 & 27 & 17 & 16.1 & 13.5 & 21.2 & 16.3 & 15.9 & 15.8 & 16.6 & 12.1 & 15.9 & 12.3 \\
\hline $\mathrm{Pb}$ & & & & & & & & & & & & & & & 1.26 & 1.3 & 1.02 & \\
\hline La & 0.025 & 0.027 & 0.26 & 0.4 & 1.49 & 1.76 & 14.4 & 3.64 & 1.4 & 2.02 & 8.29 & 4.74 & 4.29 & 4.64 & 2.96 & 3.84 & 4.18 & 4.7 \\
\hline $\mathrm{Ce}$ & 0.064 & 0.087 & 0.786 & 1.271 & 3.51 & 3.55 & 35.7 & 8.39 & 4.26 & 4.75 & 19.9 & 12.5 & 11.6 & 12.1 & 7.73 & 9.24 & 10.49 & 10.69 \\
\hline $\mathrm{Pr}$ & 0.011 & 0.017 & 0.122 & 0.235 & 0.494 & 0.492 & 5.1 & 1.23 & 0.753 & 0.692 & 2.79 & 1.85 & 1.75 & 1.8 & 1.17 & 1.35 & 1.48 & 1.38 \\
\hline $\mathrm{Nd}$ & 0.06 & 0.1 & 0.542 & 1.347 & 2.38 & 2.28 & 23.8 & 6.06 & 4.31 & 3.43 & 12.9 & 9.03 & 8.52 & 8.82 & 5.85 & 6.53 & 7.45 & 7.29 \\
\hline $\mathrm{Sm}$ & 0.024 & 0.046 & 0.148 & 0.495 & 0.705 & 0.648 & 5.95 & 2 & 1.66 & 1.12 & 3.39 & 2.7 & 2.6 & 2.6 & 1.84 & 1.79 & 2.51 & 2.1 \\
\hline Eu & 0.003 & 0.009 & 0.09 & 0.144 & 0.311 & 0.304 & 2 & 0.682 & 0.593 & 0.399 & 1.09 & 0.89 & 0.88 & 0.88 & 0.64 & 0.55 & 0.76 & 0.64 \\
\hline Gd & 0.036 & 0.08 & 0.209 & 0.783 & 0.856 & 0.843 & 6.23 & 2.75 & 2.46 & 1.64 & 3.97 & 3.25 & 3.2 & 3.17 & 2.81 & 2.09 & 3.12 & 2.4 \\
\hline $\mathrm{Tb}$ & 0.007 & 0.017 & 0.04 & 0.151 & 0.154 & 0.164 & 0.984 & 0.487 & 0.449 & 0.313 & 0.68 & 0.57 & 0.55 & 0.55 & 0.46 & 0.31 & 0.44 & 0.37 \\
\hline Dy & 0.045 & 0.116 & 0.251 & 0.961 & 1.03 & 1.07 & 5.32 & 2.95 & 2.83 & 1.59 & 3.96 & 3.23 & 3.19 & 3.14 & 2.91 & 2.23 & 3 & 2.33 \\
\hline Ho & 0.011 & 0.029 & 0.056 & 0.209 & 0.215 & 0.238 & 1.02 & 0.641 & 0.605 & 0.5 & 0.81 & 0.64 & 0.64 & 0.63 & 0.63 & 0.47 & 0.59 & 0.48 \\
\hline $\mathrm{Er}$ & 0.031 & 0.1 & 0.172 & 0.632 & 0.618 & 0.684 & 2.56 & 1.95 & 1.79 & 1.68 & 2.36 & 1.83 & 1.77 & 1.7 & 1.58 & 1.2 & 1.54 & 1.22 \\
\hline $\mathrm{Tm}$ & & & & & & & & & & & & & & & 0.25 & 0.17 & 0.22 & 0.18 \\
\hline Yb & 0.035 & 0.132 & 0.173 & 0.601 & 0.653 & 0.764 & 2.16 & 1.72 & 1.7 & 1.68 & 2.26 & 1.58 & 1.55 & 1.58 & 1.67 & 1.24 & 1.48 & 1.12 \\
\hline Lu & 0.007 & 0.026 & 0.028 & 0.092 & 0.096 & 0.112 & & 0.264 & 0.27 & 0.256 & 0.32 & 0.23 & 0.23 & 0.22 & 0.24 & 0.15 & 0.24 & 0.18 \\
\hline
\end{tabular}


Greenland grey gneisses

\begin{tabular}{|c|c|c|c|c|c|c|c|c|c|c|c|c|c|c|c|c|c|c|}
\hline \multicolumn{19}{|c|}{ tonalitic and quartz-diorite components } \\
\hline 462904 & 462945 & 462946 & 462948 & G01/113 & G93/05 & G91/49 & G93/07 & G99/22 & G97/18 & G97/31 & G97/39 & G97/38 & G93/44 & 292128 & 292127 & G97/30 & 292483 & 292489 \\
\hline bon-Isua & bon-Isua & bon-Isua & bon-Isua & tonalite & tonalite & tonalite & tonalite & tonalite & tonalite & tonalite & tonalite & tonalite & tonalite & qtz-diorite & qtz-diorite & qtz-diorite & qtz-diorite & qtz-diorite \\
\hline$\sim 3700 \mathrm{Ma}$ & $-3700 \mathrm{Ma}$ & $-3700 \mathrm{Ma}$ & $\sim 3700 \mathrm{Ma}$ & $3849 \mathrm{Ma}$ & $3842 \mathrm{Ma}$ & $3850 \mathrm{Ma}$ & $3852 \mathrm{Ma}$ & $3862 \mathrm{Ma}$ & $3808 \mathrm{Ma}$ & $3809 \mathrm{Ma}$ & $3818 \mathrm{Ma}$ & $3811 \mathrm{Ma}$ & $3806 \mathrm{Ma}$ & $3806 \mathrm{Ma}$ & $-3800 \mathrm{Ma}$ & $-3800 \mathrm{Ma}$ & $-3800 \mathrm{Ma}$ & $-3800 \mathrm{Ma}$ \\
\hline 48.62 & 50.13 & 51.57 & 54 & 69.59 & 67.65 & 69.04 & 67.29 & 66.92 & 69.79 & 66.79 & 69.81 & 70.13 & 70.02 & 54.73 & 56.58 & 60.21 & 61.94 & 62.5 \\
\hline 0.2 & 0.32 & 0.36 & 0.4 & 0.27 & 0.41 & 0.31 & 0.49 & 0.51 & 0.25 & 0.31 & 0.26 & 0.25 & 0.27 & 0.91 & 0.81 & 1.03 & 0.57 & 0.47 \\
\hline 14.09 & 17.96 & 18.34 & 17.74 & 15.54 & 16.03 & 15.52 & 15.55 & 16.09 & 16.7 & 17.93 & 16.67 & 16.74 & 16.45 & 19.1 & 18.2 & 15.36 & 15.21 & 14.56 \\
\hline 10.68 & 11.12 & 10.62 & 9.3 & 2.24 & 3.76 & 2.84 & 4.1 & 3.5 & 2.12 & 2.36 & 2.15 & 2.05 & 1.95 & 7.16 & $\begin{array}{l}1.78 \\
4.67\end{array}$ & 7.64 & $\begin{array}{r}1.28 \\
4.2\end{array}$ & $\begin{array}{l}1.85 \\
4.68\end{array}$ \\
\hline 0.24 & 0.19 & 0.17 & 0.13 & 0.03 & 0.06 & 0.04 & 0.07 & 0.06 & 0.03 & 0.03 & 0.03 & 0.03 & 0.02 & 0.1 & 0.07 & 0.12 & 0.07 & 0.06 \\
\hline 12.46 & 8.97 & 8.46 & 7.05 & 2.5 & 2.39 & 2.59 & 1.53 & 1.32 & 0.94 & 1.2 & 0.94 & 0.89 & 0.96 & 3.37 & 3.35 & 3.8 & 1.55 & 1.27 \\
\hline 12.82 & 8.54 & 7.11 & 8.39 & 4.38 & 4.53 & 5.82 & 4.45 & 4.61 & 3.94 & 5.02 & 3.95 & 3.93 & 3.57 & 7.71 & 6.4 & 4.57 & 4.32 & 4.66 \\
\hline 0.76 & 2.6 & 3.24 & 2.85 & 3.12 & 3.7 & 1.5 & 4.78 & 4.95 & 5.22 & 5.4 & 5.17 & 5.33 & 5.14 & 4.87 & 4.78 & 3.28 & 4.05 & 3.55 \\
\hline 0.11 & 0.14 & 0.1 & 0.12 & 1.57 & 1.45 & 1.79 & 1.17 & 1.03 & 0.93 & 0.79 & 0.87 & 0.98 & 1.08 & 1.28 & 1.62 & 2.85 & 2.15 & 1.97 \\
\hline 0.01 & 0.02 & 0.02 & 0.02 & 0.07 & 0.12 & 0.06 & 0.14 & 0.14 & 0.01 & 0.07 & 0.08 & 0.07 & 0.08 & 0.29 & 0.27 & 0.44 & 0.16 & 0.18 \\
\hline 1.7 & 2.63 & 1.72 & 1.76 & & & & & & & & & & & & 1.64 & & 1.39 & 1.19 \\
\hline 1922 & 196 & 204 & 141 & & & & & & & & & & & & 77 & & 22 & 26 \\
\hline 68 & 44 & 49 & 35 & 4.3 & 11 & 31 & 30.9 & 6.7 & 32 & 37 & 30 & 36 & 54 & 36 & 8 & & 40 & 41 \\
\hline 560 & 103 & 96 & 69 & 30.8 & 43 & 34 & 26 & 31 & & & 17 & 15 & 12 & 44 & 50 & & 17 & 10 \\
\hline 1.9 & 5.1 & 1.2 & 4.3 & 66.7 & 94 & 58 & 25.1 & 16.5 & 31 & 26 & 27 & 37 & 53 & 35 & 53 & & 103 & 93 \\
\hline 40 & 76 & 118 & 116 & 96 & 128 & 123 & 337.7 & 350.4 & 429 & 469 & 424 & 431 & 394 & 642 & 669 & & 417 & 392 \\
\hline 6 & 12 & 17 & 14 & 120.7 & 90 & 97 & 115.2 & 93.5 & 100 & 87 & 93 & 122 & 136 & 163 & 224 & & 257 & 197 \\
\hline \multirow[t]{2}{*}{161} & 212 & 189 & 195 & & 40 & 19 & & & 21 & 26 & 19 & 19 & 19 & 115 & 78 & & 56 & 49 \\
\hline & & & & 0.27 & 0.3 & 0.52 & & & & & & & & & & & & \\
\hline 0.243 & 0.533 & 0.584 & 0.552 & 3.2 & 4.4 & 3.1 & 3.9 & 4.5 & 1.3 & 1.2 & 1.2 & 1.3 & 1.6 & 5.6 & 6.9 & & 10 & 9 \\
\hline 16.5 & 23.6 & 23.4 & 27.5 & 141.3 & 118 & 122 & 142.6 & 157.8 & 121 & 115 & 122 & 125 & 109 & 54 & 53 & & 194 & 197 \\
\hline \multirow[t]{2}{*}{0.135} & 0.168 & 0.197 & 0.229 & 2.1 & 2.02 & 0.42 & 0.18 & 0.2 & 0.77 & 0.38 & 0.63 & 0.79 & 0.43 & 1.31 & 3 & & & \\
\hline & & & & 0.3 & 0.41 & 0.25 & 0.12 & 0.1 & 0.32 & 0.24 & 0.27 & 0.33 & 0.23 & 1.05 & & & & \\
\hline 9 & 10 & 10.8 & 13 & 3.3 & 8.1 & 2.1 & 8.1 & 9.5 & 2.9 & 3.5 & 2.9 & 3 & 1.4 & 18.2 & 17 & & 33 & 21 \\
\hline 2.3 & & 4.2 & 3.91 & 11.1 & 10.6 & 4.4 & & 8.4 & 6.5 & 10.3 & 6.8 & 9 & 12 & 15.2 & 15 & & 20 & 22 \\
\hline 1.032 & 0.676 & 1.039 & 1.262 & & 13.4 & 10.1 & 14.5 & & 5.81 & 4.83 & 5.17 & 5.17 & 4.23 & 20.2 & & & & \\
\hline 2.476 & 1.823 & 2.54 & 3.084 & 24.2 & 29.8 & 19.5 & 32.2 & 28.8 & 11.4 & 9.8 & 9.7 & 10.3 & 7.7 & 53.6 & & & & \\
\hline 0.349 & 0.273 & 0.367 & 0.459 & 2.7 & 3.94 & 2.32 & 4.1 & 3.8 & 1.48 & 1.38 & 1.54 & 1.31 & 0.9 & 8.29 & & & & \\
\hline 1.664 & 1.401 & 1.857 & 2.278 & 10 & 15.3 & 8.5 & 16.5 & 16.1 & 6.05 & 6.18 & 5.95 & 5.89 & 3.37 & 37.4 & & & & \\
\hline 0.615 & 0.552 & 0.687 & 0.912 & 1.69 & 2.58 & 1.4 & 3.09 & 3.12 & 1.3 & 1.23 & 1.2 & 1.38 & 0.64 & 7.41 & & & & \\
\hline 0.196 & 0.229 & 0.22 & 0.283 & 0.54 & 0.65 & 0.58 & 0.89 & 1 & 0.48 & 0.54 & 0.42 & 0.45 & 0.37 & 1.94 & & & & \\
\hline 0.879 & 0.856 & 1.057 & 1.318 & 1.25 & 2.09 & 0.84 & 2.42 & 2.74 & 0.91 & 1.14 & 0.84 & 0.98 & 0.47 & 5.19 & & & & \\
\hline 0.177 & 0.174 & 0.209 & 0.262 & 0.13 & 0.29 & 0.1 & 0.32 & 0.34 & 0.13 & 0.15 & 0.14 & 0.19 & 0.05 & 0.66 & & & & \\
\hline 1.358 & 1.431 & 1.721 & 2.039 & 0.71 & 1.6 & 0.54 & 1.64 & 1.98 & 0.63 & 0.75 & 0.65 & 0.56 & 0.29 & 3.63 & & & & \\
\hline 0.349 & 0.357 & 0.462 & 0.537 & 0.12 & 0.33 & 0.11 & 0.29 & 0.35 & 0.12 & 0.11 & 0.11 & 0.1 & 0.06 & 0.68 & & & & \\
\hline 1.303 & 1.278 & 1.679 & 1.914 & 0.31 & 0.83 & 0.27 & 0.75 & 0.96 & 0.27 & 0.3 & 0.29 & 0.26 & 0.15 & 1.74 & & & & \\
\hline 0.206 & 0.192 & 0.249 & 0.281 & & & & & & & & & & & & & & & \\
\hline 1.447 & 1.344 & 1.653 & 1.832 & 0.29 & 0.84 & 0.27 & 0.63 & 0.82 & 0.28 & 0.29 & 0.33 & 0.3 & 0.17 & 1.52 & & & & \\
\hline 0.217 & 0.22 & 0245 & 0.278 & 0.044 & 011 & 0.036 & 0.093 & 012 & 0.039 & 0.045 & 048 & 0.035 & 0.027 & 02 & & & & \\
\hline
\end{tabular}


Anshan area Eoarchaean orthogneisses

\begin{tabular}{|c|c|c|c|c|c|c|c|c|c|c|c|c|c|c|c|c|c|c|}
\hline & & & & & & & & & & & & & & & \multicolumn{4}{|c|}{ tonalitic and quartz-dioritic components } \\
\hline G97/97 & G97/98 & VM90/02 & 229404 & 229403 & 237000 & 225892 & 225893 & 236999 & 236991 & 225989 & 225990 & VM90/08 & 248054 & $248046 \mathrm{~A}$ & A9011 & A0518 & A9604 & A0512 \\
\hline tonalite & tonalite & tonalite & qtz-diorite & qtz-diorite & qtz-diorite & tonalite & tonalite & tonalite & tonalite & qtz-diorite & qtz-diorite & qtz-diorite & qtz-diorite & \begin{tabular}{l|} 
tonalite \\
\end{tabular} & trondhj & trondhj & qtz-diorite & trondh \\
\hline$\sim 3795 \mathrm{Ma}$ & $3795 \mathrm{Ma}$ & $3760 \mathrm{Ma}$ & $\sim 3700$ & -3700 & -3700 & -3700 & -3700 & $\sim 3700$ & $\begin{array}{c}-3700 \\
\end{array}$ & $\sim 3700$ & $\sim 3700$ & $-3650 \mathrm{Ma}$ & $-3650 \mathrm{Ma}$ & $-3650 \mathrm{Ma}$ & 3804 & 3800 & 3794 & 3777 \\
\hline 71.75 & 69.23 & 70.38 & 59.86 & $\begin{array}{l}61.7 \\
\end{array}$ & 64.12 & 69.27 & 69.29 & 65.97 & 68.02 & 60.89 & 61.62 & 50.42 & 53.44 & $\begin{array}{l}72.14 \\
\end{array}$ & 74.29 & 74.39 & 57.88 & 70.53 \\
\hline 0.3 & 0.33 & 0.31 & 0.84 & 0.73 & 0.47 & 0.42 & 0.43 & 0.45 & 0.41 & 0.67 & 0.69 & 0.57 & 0.55 & 0.26 & 0.10 & 0.08 & 0.61 & 0.28 \\
\hline 15.1 & 16.19 & 15.89 & 16.33 & 15.79 & 14.76 & 15.91 & 15.74 & 14.41 & 15.22 & 14.88 & 15.38 & 16.89 & 17.43 & 15 & 15.62 & 14.73 & 18.99 & 15.61 \\
\hline 2.47 & 2.61 & 2.35 & 1.55 & 1.61 & 2.22 & 0.58 & 0.57 & 1.84 & 1.29 & 1.26 & 1.67 & 8.43 & 0.89 & 0.33 & 0.21 & 0.52 & 5.00 & 0.86 \\
\hline & & & 4.72 & 4.23 & 5.12 & 2.43 & 2.38 & 4.6 & 2.66 & 4.74 & 3.82 & & 6.67 & 1.65 & 0.92 & 0.40 & & 1.87 \\
\hline 0.04 & 0.05 & 0.03 & 0.1 & 0.09 & 0.08 & 0.04 & 0.04 & 0.07 & 0.04 & 0.09 & 0.08 & 0.13 & 0.16 & 0.06 & 0.03 & 0.01 & 0.15 & 0.03 \\
\hline 0.71 & 0.96 & 0.7 & 3.47 & 3.21 & 1.25 & 0.92 & 0.99 & 1.06 & 1.17 & 2.59 & 2.96 & 5.92 & 5.42 & 0.66 & 0.22 & 0.16 & 2.65 & 1.33 \\
\hline 2.82 & 3.44 & 2.73 & 5.73 & 5.23 & 4.51 & 2.92 & 3.2 & 4.06 & 3.66 & 4.68 & 4.47 & 8.88 & 7.69 & 2.18 & 1.48 & 1.46 & 4.52 & 0.49 \\
\hline 4.73 & 4.89 & 4.99 & 4.44 & 4.01 & 3.77 & 5.06 & 4.88 & 3.74 & 4.62 & 5.19 & 4.69 & 4.18 & 4.67 & 4.67 & 4.72 & 5.71 & 5.56 & 5.18 \\
\hline 1.86 & 1.66 & 1.41 & 1.45 & 1.68 & 1.92 & 1.66 & 1.51 & 1.94 & 1.41 & 0.63 & 1.13 & 0.89 & 1.34 & 2.5 & 1.88 & 1.04 & 2.53 & 2.00 \\
\hline 0.01 & 0.01 & 0.09 & 0.23 & 0.22 & 0.21 & 0.14 & 0.14 & 0.19 & 0.14 & 0.19 & 0.21 & 0.09 & 0.09 & 0.06 & 0.00 & 0.01 & 0.20 & 0.08 \\
\hline & & 0.96 & 1.03 & 0.96 & 0.92 & 0.52 & 0.6 & 0.87 & 0.71 & 2.73 & 2.55 & 0.71 & 1.28 & 0.47 & & 0.70 & & 1.28 \\
\hline & & & 109 & 100 & 15 & 15 & 16 & 22 & 14 & 89 & 86 & 44.4 & 82 & 10 & 18 & 4.73 & & 9.78 \\
\hline 4 & 5 & & 60 & 65 & 49 & 57 & 58 & 46 & 52 & 43 & 32 & & 31 & 9 & & & & \\
\hline 12 & 17 & & 56 & 53 & 6 & 4 & 4 & 7 & 2 & 37 & 41 & 97 & 98 & 68 & & & & \\
\hline 78 & 72 & & 79 & 106 & 64 & 73 & 54 & 75 & 87 & 26 & 49 & 25.9 & 71 & 80 & 70 & 48.2 & 216 & 125 \\
\hline 236 & 294 & & 433 & 380 & 267 & 416 & 490 & 244 & 263 & 258 & 319 & 170.9 & 222 & 199 & 376 & 497 & 371 & 95.3 \\
\hline 212 & 204 & & 325 & 344 & 334 & 313 & 373 & 325 & 199 & 106 & 248 & 39.9 & 112 & 232 & 729 & 457 & 313 & 410 \\
\hline 17 & 22 & & 95 & 86 & 46 & 28 & 23 & 41 & 35 & 67 & 69 & & 120 & 36 & & & & \\
\hline & & & & & & & & & & & & & & & & 0.25 & & 1.71 \\
\hline 4.3 & 3.8 & & 9 & 8 & 10 & 6 & 4 & 8 & 9 & 8 & 9 & 3.2 & 3 & 7 & 2 & 2.82 & 5 & 11.8 \\
\hline 124 & 86 & & 161 & 135 & 158 & 168 & 179 & 174 & 169 & 136 & 146 & 92.4 & 67 & 124 & 103 & 71.7 & 157 & 138 \\
\hline 4.14 & 3.73 & & 4 & 6 & 1 & 8 & 7 & 5 & 4 & 3 & 11 & & & & 5 & 4.82 & 5 & 4.22 \\
\hline 0.82 & 1.2 & & & & & & & & & & & & & & & 1.63 & & 1.13 \\
\hline 8.6 & 16.3 & & 24 & 23 & 26 & 5 & 5 & 19 & 20 & 20 & 23 & 15 & 14 & 7 & 3 & 2.84 & 39 & 10.8 \\
\hline 13.9 & 15.1 & & 16 & 16 & 12 & 20 & 10 & 13 & 17 & 8 & 12 & & 19 & 9 & & & & \\
\hline 21.6 & 15 & & & & & 24.1 & & 22.8 & 16.9 & & & 6.81 & & & 6.55 & 5.99 & 40.43 & 16.5 \\
\hline 41.1 & 25 & & & & & 44.1 & & 44.7 & 36.6 & & & 12.1 & & & 9.59 & 7.16 & 79.09 & 27.2 \\
\hline 4.68 & 3.34 & & & & & & & & & & & 2.54 & & & 2.45 & 1.10 & 7.5 & 2.81 \\
\hline 16.6 & 13.5 & & & & & & & & & & & 11.4 & & & 5.4 & 3.88 & 28.55 & 9.48 \\
\hline 2.81 & 2.92 & & & & & 3.19 & & 3.94 & 4.24 & & & 2.78 & & & 1.78 & 0.79 & 8 & 1.80 \\
\hline 0.74 & 0.65 & & & & & 0.726 & & 1.34 & 0.926 & & & 0.672 & & & 0.46 & 0.33 & 2.35 & 0.33 \\
\hline 1.93 & 2.79 & & & & & & & & & & & 2.78 & & & 1.56 & 0.68 & 7.26 & 1.80 \\
\hline 0.28 & 0.39 & & & & & & & 0.51 & 0.436 & & & 0.454 & & & 0.3 & 0.10 & 1.3 & 0.30 \\
\hline 1.58 & 2.86 & & & & & & & & & & & 2.53 & & & 0.76 & 0.60 & 7.44 & 1.80 \\
\hline 0.29 & 0.54 & & & & & & & & & & & 0.507 & & & 0.2 & 0.11 & 1.45 & 0.37 \\
\hline 0.92 & 1.58 & & & & & & & & & & & 1.39 & & & 0.49 & 0.34 & 3.93 & 1.14 \\
\hline & & & & & & & & & & & & & & & 0.1 & 0.05 & 0.59 & 0.18 \\
\hline 0.88 & 1.62 & & & & & 0.202 & & 1.32 & 1.33 & & & 1.35 & & & 0.41 & 0.34 & 3.81 & 1.19 \\
\hline 0.13 & 0.25 & & & & & 0.031 & & 0.179 & 0.187 & & & & & & 0.1 & 0.05 & 0.56 & 0.18 \\
\hline
\end{tabular}




\begin{tabular}{ccccc}
\hline \multicolumn{7}{c}{} & & & & \\
\hline A0423 & A0404 & A0405-1 & A0405-2 & A9011 \\
\hline trondhj & trondhj & trondhj & trondhj & trondhj \\
\hline 3680 & 3620 & 3573 & 3573 & 3804 \\
\hline 71.10 & 76.10 & 73.03 & 76.18 & 74.29 \\
0.37 & 0.09 & 0.18 & 0.03 & 0.10 \\
15.34 & 13.39 & 14.83 & 13.40 & 15.62 \\
2.19 & 0.86 & 1.07 & 0.17 & 0.21 \\
0.66 & 0.20 & 0.40 & 0.22 & 0.92 \\
0.05 & 0.02 & 0.02 & 0.02 & 0.03 \\
0.83 & 0.43 & 0.54 & 0.23 & 0.22 \\
1.43 & 1.86 & 1.41 & 0.72 & 1.48 \\
4.49 & 5.86 & 5.00 & 5.02 & 4.72 \\
2.39 & 0.48 & 2.72 & 3.11 & 1.88 \\
0.07 & 0.02 & 0.05 & 0.01 & 0.00 \\
1.30 & 0.66 & 0.94 & 0.22 & \\
& & & & \\
19.0 & 11.1 & 19.9 & 11.7 & 18 \\
& & & & \\
186 & 20.7 & 83.7 & 63.3 & 70 \\
256 & 250 & 176 & 108 & 376 \\
517 & 81.0 & 403 & 262 & 729 \\
& & & & \\
1.24 & 0.26 & 0.89 & 0.41 & \\
9.87 & 2.35 & 6.15 & 2.05 & 2 \\
169 & 81.9 & 116 & 35.2 & 103 \\
6.02 & 10.6 & 12.4 & 9.13 & 5 \\
0.46 & 0.97 & 1.93 & 2.33 & \\
34.4 & 4.60 & 12.2 & 11.2 & 3 \\
& & & & \\
& & & & \\
36.8 & 7.91 & 19.3 & 2.81 & 6.55 \\
50.1 & 14.6 & 25.3 & 4.16 & 9.59 \\
6.57 & 1.49 & 3.41 & 0.55 & 2.45 \\
22.9 & 5.03 & 11.5 & 2.00 & 5.4 \\
5.15 & 1.07 & 2.36 & 0.55 & 1.78 \\
0.86 & 0.39 & 0.54 & 0.13 & 0.46 \\
4.91 & 0.96 & 2.10 & 0.85 & 1.56 \\
0.85 & 0.13 & 0.33 & 0.21 & 0.3 \\
4.84 & 0.88 & 1.84 & 1.68 & 0.76 \\
0.92 & 0.16 & 0.42 & 0.39 & 0.2 \\
2.66 & 0.46 & 1.20 & 1.21 & 0.49 \\
0.40 & 0.06 & 0.16 & 0.19 & 0.1 \\
2.97 & 0.45 & 1.05 & 1.31 & 0.41 \\
0.44 & 0.08 & 0.14 & 0.19 & 0.1 \\
\hline & & & &
\end{tabular}

